\title{
From preassociation to chelation: a survey of cisplatin interaction with methionine at molecular level by IR ion spectroscopy and computations
}

\author{
Roberto Paciotti, ${ }^{1 \ddagger}$ Davide Corinti, ${ }^{2 \ddagger}$ Philippe Maitre, ${ }^{3}$ Cecilia Coletti, ${ }^{1}$ Nazzareno $R e,{ }^{1}$ Barbara \\ Chiavarino, ${ }^{2}$ Maria Elisa Crestoni, ${ }^{2}$ and Simonetta Fornarini ${ }^{2 *}$ \\ ${ }^{1}$ Dipartimento di Farmacia, Università G. D'Annunzio Chieti-Pescara, Via dei Vestini 31, Chieti I-66100, Italy \\ 2 Dipartimento di Chimica e Tecnologie del Farmaco, Università di Roma "La Sapienza", I-00185 Roma, Italy \\ ${ }^{3}$ Institut de Chimie Physique, Université Paris-Saclay, CNRS, F-91405 Orsay, France
}

Corresponding author's e-mail : simonetta.fornarini@uniroma1.it

Table of contents

p. S2 Figure S1. Mass spectrum of a solution of cisplatin and methionine (1:1) $5 \times 10^{-5} \mathrm{M}$ in methanol/water (50/50, v/v) recorded with an Esquire 6000 ion trap mass spectrometer.

p. S2 Figure S2. Mass spectrum recorded upon selection and irradiation at $1273 \mathrm{~cm}^{-1}$ of cis$\left[\mathrm{PtCl}\left(\mathrm{NH}_{3}\right)_{2}\left(\mathrm{H}_{2} \mathrm{O}\right)(\mathrm{Met})\right]^{+}$ions at $\mathrm{m} / \mathrm{z} 430$.

p. S3 Figure S3. IRMPD profiles of the primary fragmentation channels from [PtCl$\left.\left(\mathrm{NH}_{3}\right)_{2}\left(\mathrm{H}_{2} \mathrm{O}\right)(\mathrm{Met})\right]^{+}$ involving cleavage of either neutral methionine or $\mathrm{H}_{2} \mathrm{O}$.

p. S4 Figure S4. Mass spectrum recorded upon selection and irradiation at $1150 \mathrm{~cm}^{-1}$ of $\left[\mathrm{PtCl}\left(\mathrm{NH}_{3}\right)(\mathrm{Met})\right]^{+}$ ions at $m / z 395$.

p. S5 Figure S5. Optimized geometries for ch1 and ch2 isomers, $\left[\mathrm{PtCl}\left(\mathrm{NH}_{3}\right) \mathrm{Met}\right]^{+}$.

p. S9 Figure S6. IRMPD spectrum of $\left[\mathrm{PtCl}\left(\mathrm{NH}_{3}\right)(\mathrm{Met})\right]^{+}$(blue profile) compared with the calculated IR spectra (black profiles) of the lowest lying conformers of the ch1 and ch2 families, computed at B3LYP/BS1 level of theory.

p. S14 Figure S7. Optimized geometries for ec2 isomers, $\left\{\right.$ cis- $\left.\left[\mathrm{PtCl}\left(\mathrm{NH}_{3}\right)_{2} \mathrm{Met}\right]^{+} \bullet \mathrm{H}_{2} \mathrm{O}\right\}$.

p. S15 Figure S8. Optimized geometries for ec1 isomers, $\left\{\right.$ cis- $\left[\mathrm{PtCl}\left(\mathrm{NH}_{3}\right)_{2}\left(\mathrm{H}_{2} \mathrm{O}\right)\right]^{+} \bullet$ Met $\}$ and $\{$ cis$\left.\left[\mathrm{PtCl}\left(\mathrm{NH}_{3}\right)_{2}(\mathrm{OH})\right] \cdot \mathrm{MetH}^{+}\right\}$.

p. S19 Figure S9. IRMPD spectrum of $\left[\mathrm{PtCl}\left(\mathrm{NH}_{3}\right)_{2}\left(\mathrm{H}_{2} \mathrm{O}\right)(\mathrm{Met})\right]^{+}$(red profile) compared with the calculated IR spectra (black profiles) of the lowest lying geometries of the ec2 and ec1 isomer families, computed at B3LYP/BS1 level of theory.

p. S24 Figure S10. structure of transition state participating in the reaction pathway for the aqua ligand substitution reaction of cis- $\left[\mathrm{PtCl}\left(\mathrm{NH}_{3}\right)_{2}\left(\mathrm{H}_{2} \mathrm{O}\right)\right]^{+}$with Met.

p. S24 Figure S11. Optimized geometries of the reactant (A) and of the product (B) obtained by intrinsic reaction coordinate (IRC) calculations.

p. S25 Table S1. IRMPD absorptions of $\left[\mathrm{PtCl}\left(\mathrm{NH}_{3}\right)(\mathrm{Met})\right]^{+}$ions and calculated vibrational frequencies $\left(\mathrm{cm}^{-1}\right)$ for ch1_sr_b_1 and ch1_ss_a_2.

p. S27 Table S2. IRMPD absorptions of $\left[\mathrm{PtCl}\left(\mathrm{NH}_{3}\right)_{2}\left(\mathrm{H}_{2} \mathrm{O}\right)(\mathrm{Met})\right]^{+}$ions and calculated vibrational frequencies $\left(\mathrm{cm}^{-1}\right)$ for ec1_1 and ec1_2.

p. S25 Table S3. Cartesian coordinates of transition state computed for the aqua ligand substitution reaction of cis- $\left[\mathrm{PtCl}\left(\mathrm{NH}_{3}\right)_{2}\left(\mathrm{H}_{2} \mathrm{O}\right)\right]^{+}$with Met 


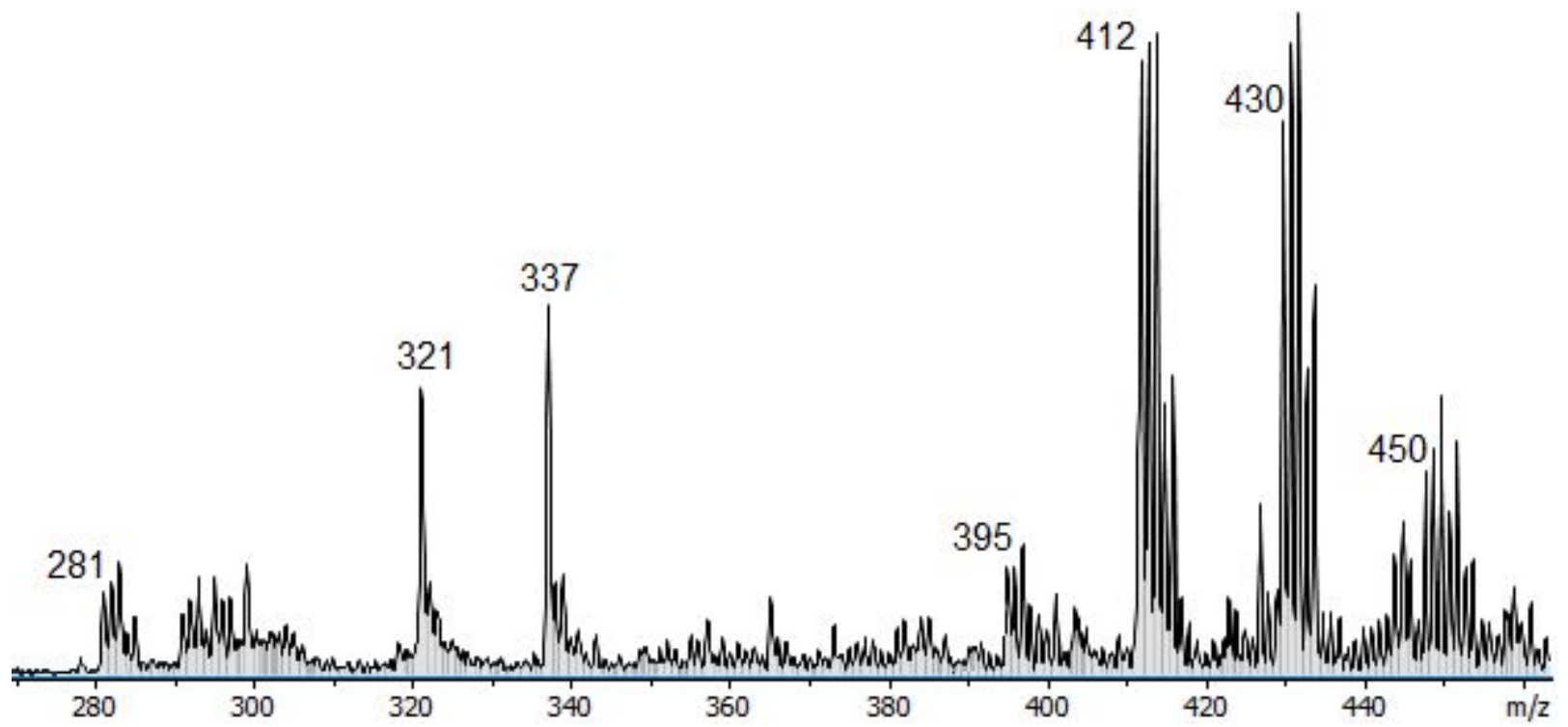

Figure S1. Mass spectrum of a solution of cisplatin and methionine $(1: 1) 5 \times 10^{-5} \mathrm{M}$ in methanol/water $(50 / 50, v / v)$ recorded with an Esquire 6000 ion trap mass spectrometer. The cluster at $\mathrm{m} / \mathrm{z}$ 412-416 corresponds to cis-[PtCl$\left.\left(\mathrm{NH}_{3}\right)_{2}(\mathrm{Met})\right]^{+}$, and the one at $\mathrm{m} / \mathrm{z}$ 430-414 to the formal five-ligand complex $\left[\mathrm{PtCl}\left(\mathrm{NH}_{3}\right)_{2} \mathrm{Met}\left(\mathrm{H}_{2} \mathrm{O}\right)\right]^{+}$. The signals at $\mathrm{m} / \mathrm{z} 321,337$ are related to Met, i.e. $\left[\mathrm{Met}_{2}+\mathrm{Na}\right]^{+}$and $\left[\mathrm{Met}_{2}+\mathrm{K}\right]^{+}$, respectively. $m / z 281-285$ is the cis- $\left[\mathrm{PtCl}\left(\mathrm{NH}_{3}\right)_{2}\left(\mathrm{H}_{2} \mathrm{O}\right)\right]^{+}$complex.

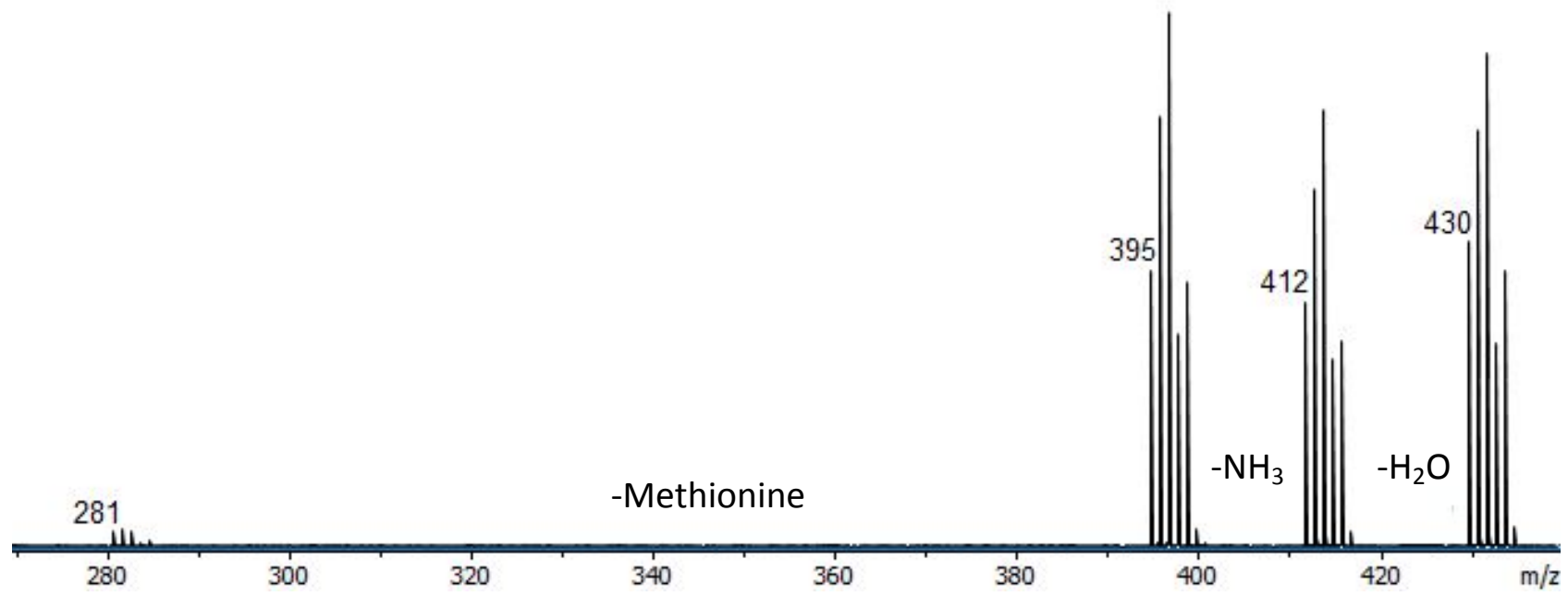

Figure S2. Mass spectrum recorded upon selection and irradiation at $1273 \mathrm{~cm}^{-1}$ of cis$\left[\mathrm{PtCl}\left(\mathrm{NH}_{3}\right)_{2}\left(\mathrm{H}_{2} \mathrm{O}\right)(\text { Met })\right]^{+}$ions at $m / z 430$. 

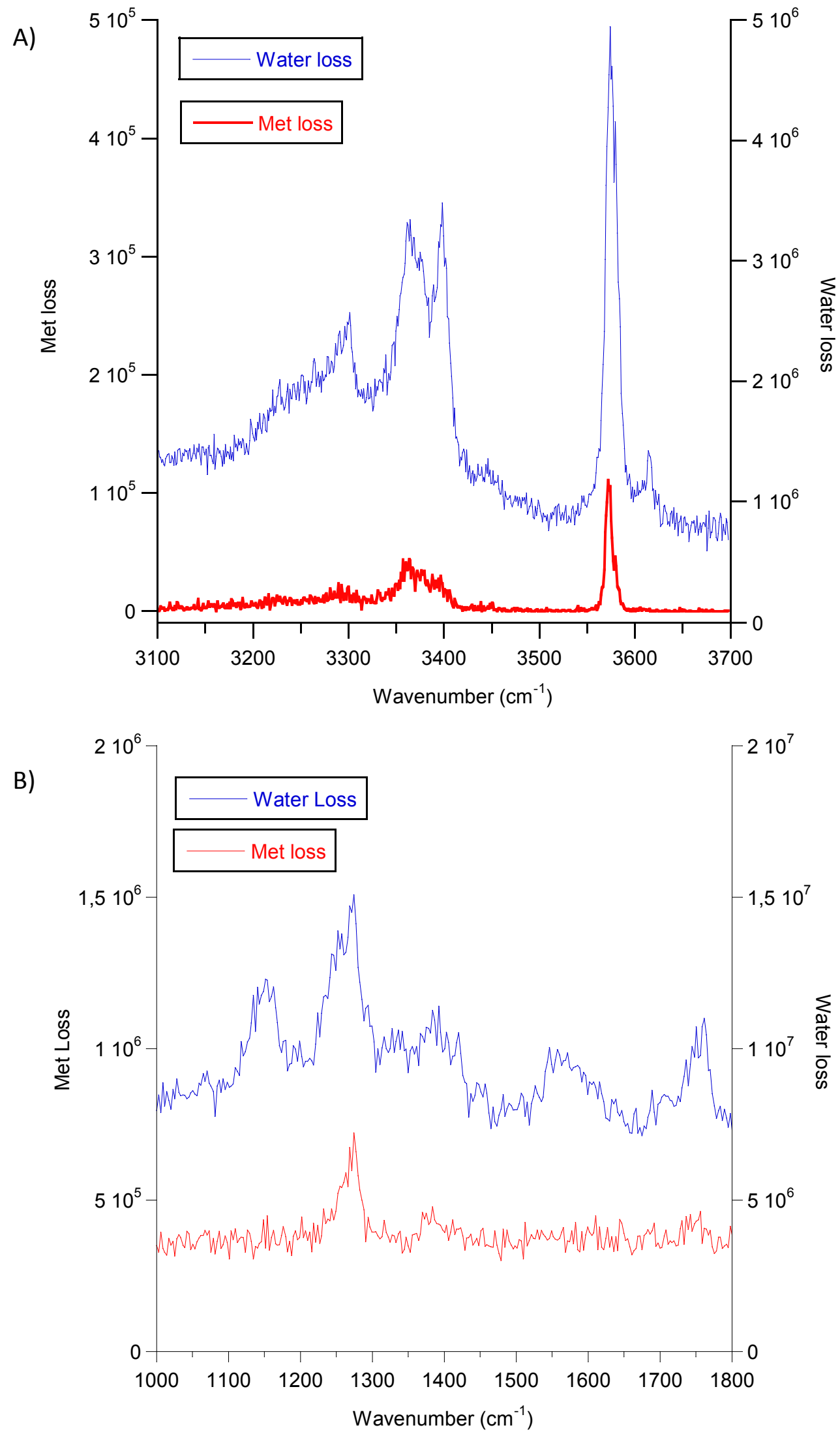

Figure S3. IRMPD profiles of the primary fragmentation channels from $\left[\mathrm{PtCl}\left(\mathrm{NH}_{3}\right)_{2}\left(\mathrm{H}_{2} \mathrm{O}\right)(\mathrm{Met})\right]^{+}$ involving cleavage of either neutral methionine (red) or $\mathrm{H}_{2} \mathrm{O}$ (blue) in $\mathrm{A}$ ) the $\mathrm{XH}$ stretching and $\mathrm{B}$ ) fingerprint regions. 


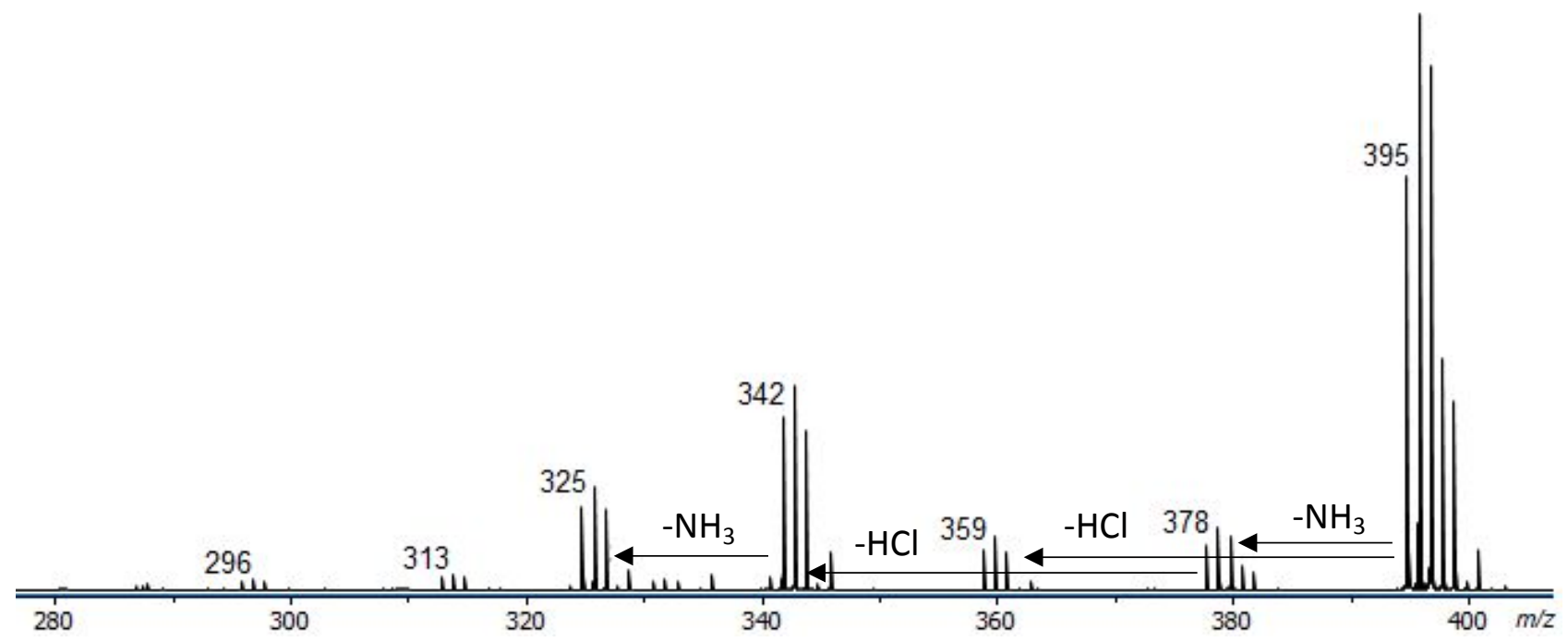

Figure S4. Mass spectrum recorded upon selection and irradiation at $1150 \mathrm{~cm}^{-1}$ of $\left[\mathrm{PtCl}\left(\mathrm{NH}_{3}\right)(\mathrm{Met})\right]^{+}$ions at $m / z 395$. 


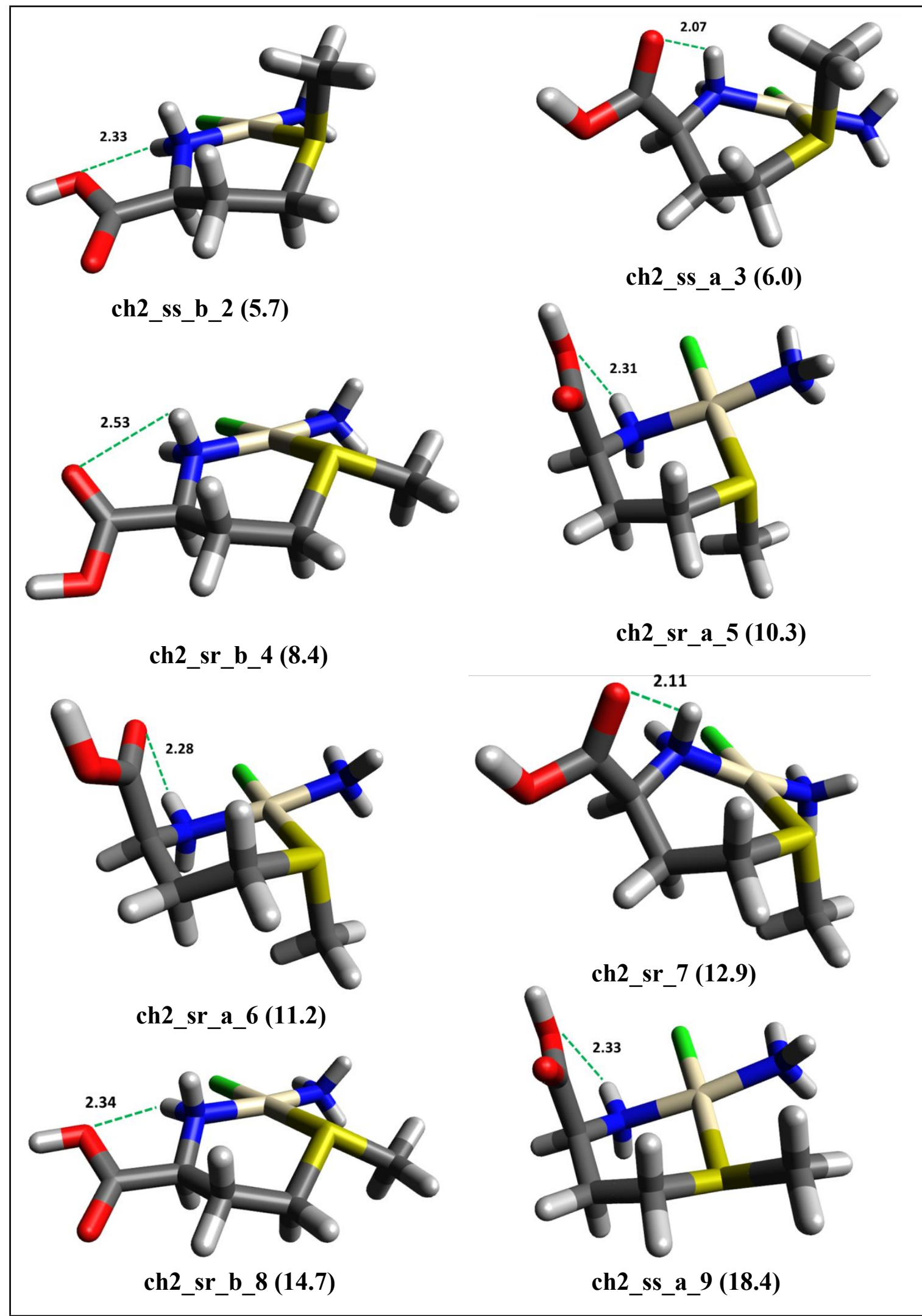

Figure S5. Optimized geometries for ch1 and ch2 isomers, [PtCl( $\left.\left.\mathrm{NH}_{3}\right) \mathrm{Met}\right]^{+}$. Relative Gibbs energy values $\left(\mathrm{kJ} \mathrm{mol}^{-1}\right)$ are reported in parenthesis. Intramolecular hydrogen bond distances $(\AA)$ are represented by green dashed lines. 


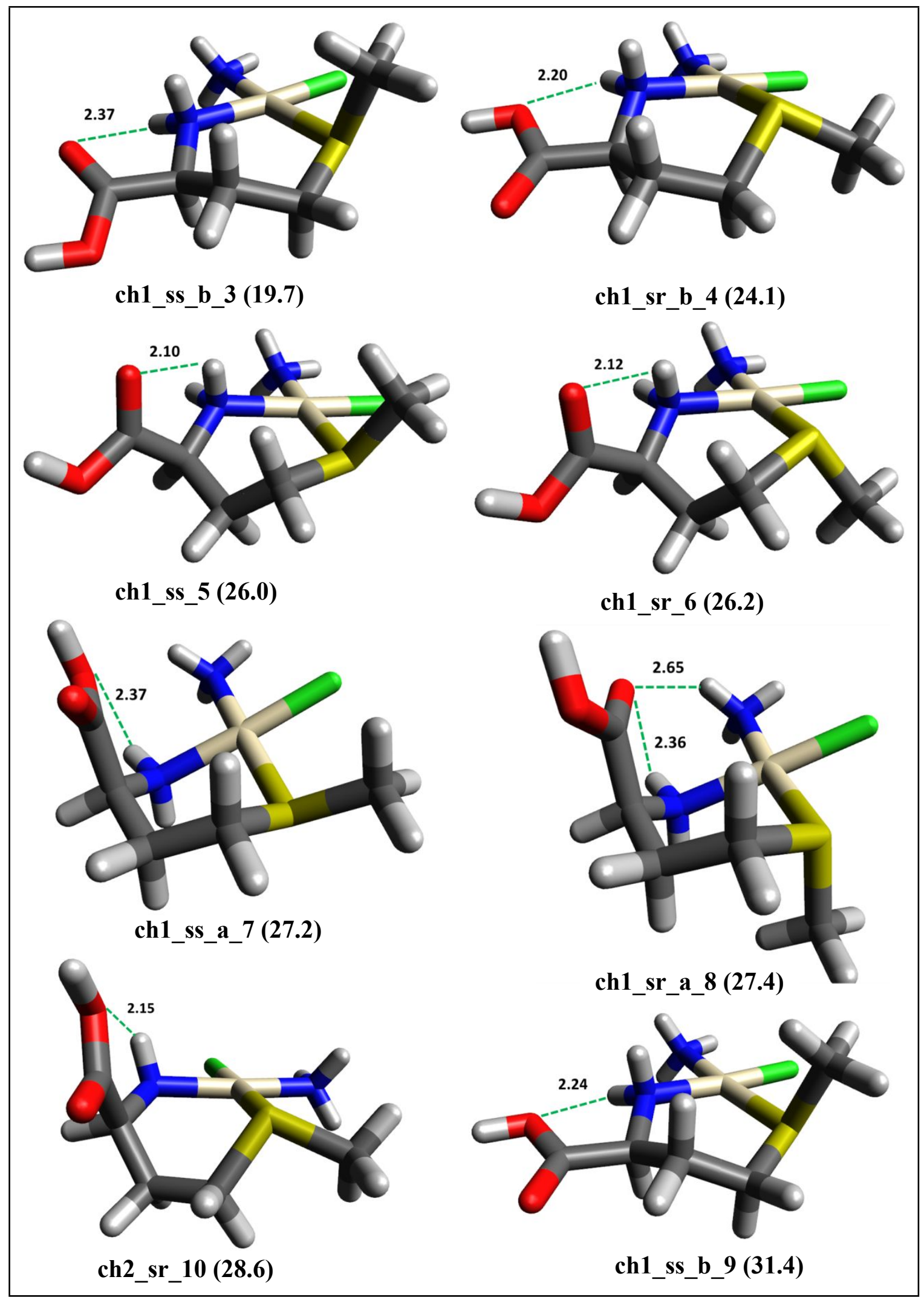

Figure S5 (continuation). Optimized geometries for ch1 and ch2 isomers, [PtCl( $\left.\left.\mathrm{NH}_{3}\right) \mathrm{Met}\right]^{+}$. Relative Gibbs energy values $\left(\mathrm{kJ} \mathrm{mol}^{-1}\right)$ are reported in parenthesis. Intramolecular hydrogen bond distances $(\AA)$ are represented by green dashed lines. 


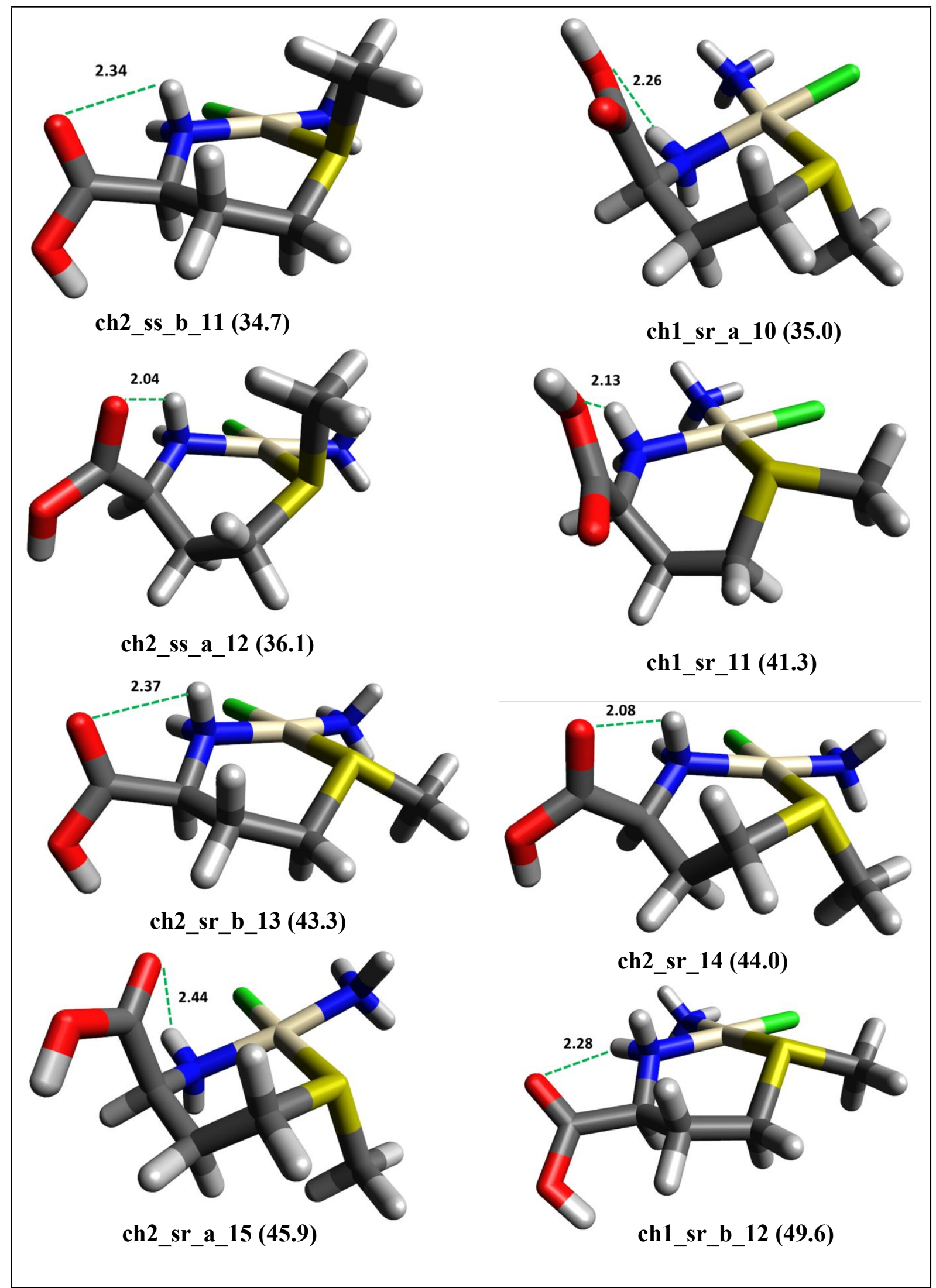

Figure S5 (continuation). Optimized geometries for ch1 and ch2 isomers, $\left[\mathrm{PtCl}\left(\mathrm{NH}_{3}\right) \mathrm{Met}\right]^{+}$. Relative Gibbs energy values $\left(\mathrm{kJ} \mathrm{mol}^{-1}\right)$ are reported in parenthesis. Intramolecular hydrogen bond distances $(\AA ̊)$ are represented by green dashed lines. 


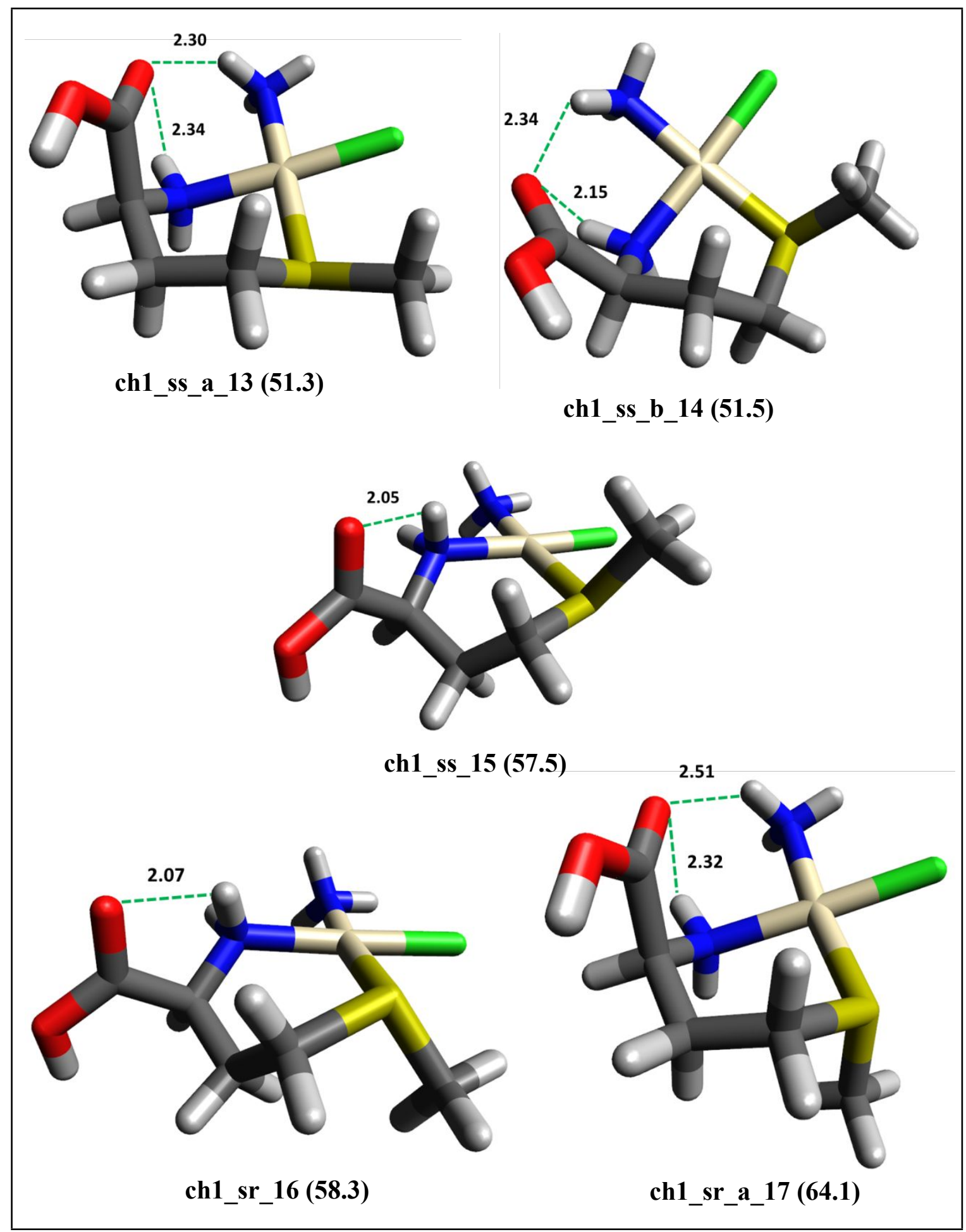

Figure S5 (continuation). Optimized geometries for ch1 and ch2 isomers, [ $\left.\mathrm{PtCl}\left(\mathrm{NH}_{3}\right) \mathrm{Met}\right]^{+}$. Relative Gibbs energy values $\left(\mathrm{kJ} \mathrm{mol}^{-1}\right)$ are reported in parenthesis. Intramolecular hydrogen bond distances $(\AA)$ are represented by green dashed lines. 


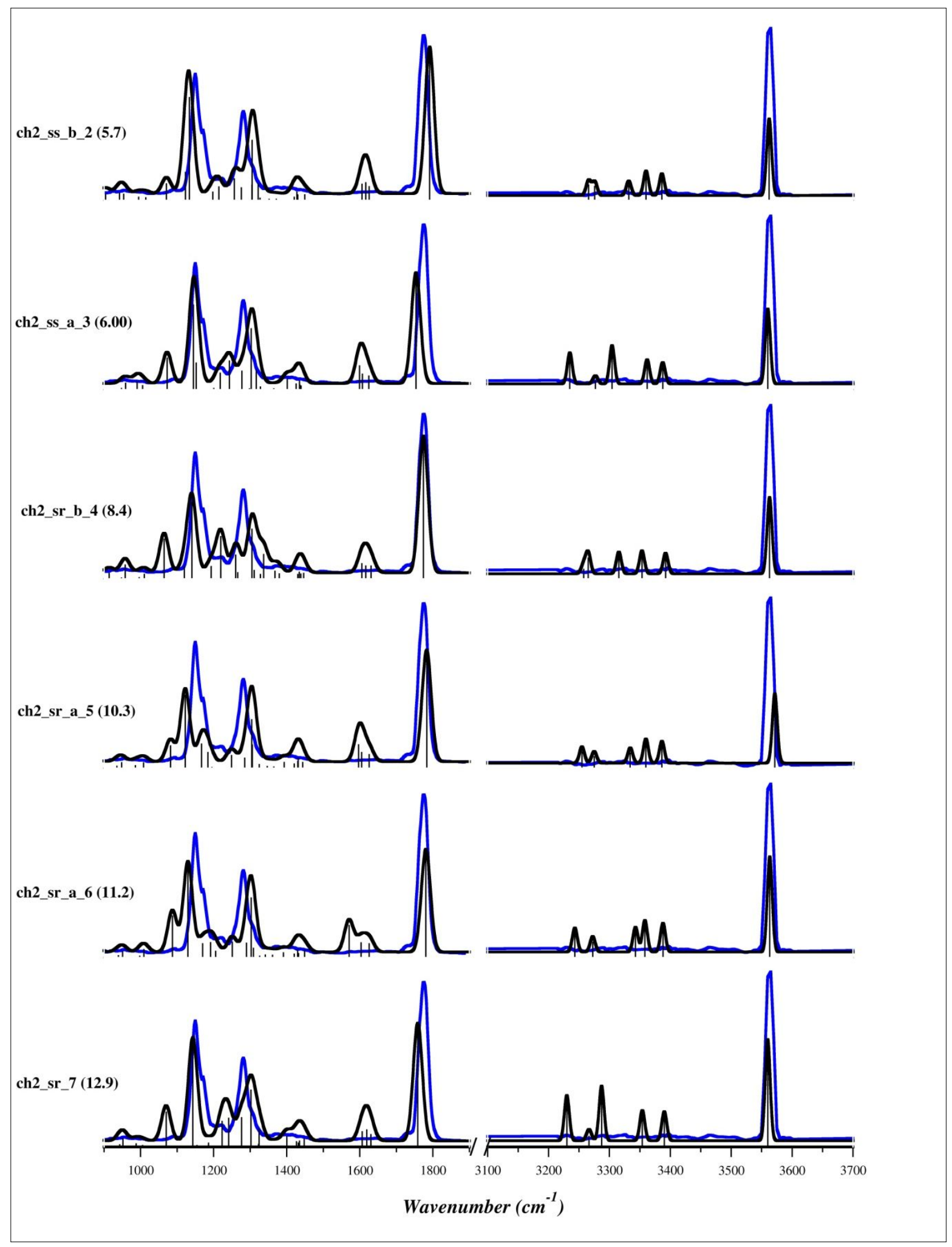

Figure S6. IRMPD spectrum of $\left[\mathrm{PtCl}\left(\mathrm{NH}_{3}\right)(\mathrm{Met})\right]^{+}$(blue profile) compared with the calculated IR spectra (black profiles) of the lowest lying conformers of the ch1 and ch2 families, computed at B3LYP/BS1 level of theory. Theoretical frequencies have been scaled by 0.974 and 0.957 in the 900-1900 $\mathrm{cm}^{-1}$ and the $3100-3700 \mathrm{~cm}^{-1}$ ranges, respectively. Free energies relative to ch2_ss_b_1 are reported in brackets $\left(\mathrm{kJ} \mathrm{mol}^{-1}\right)$. 


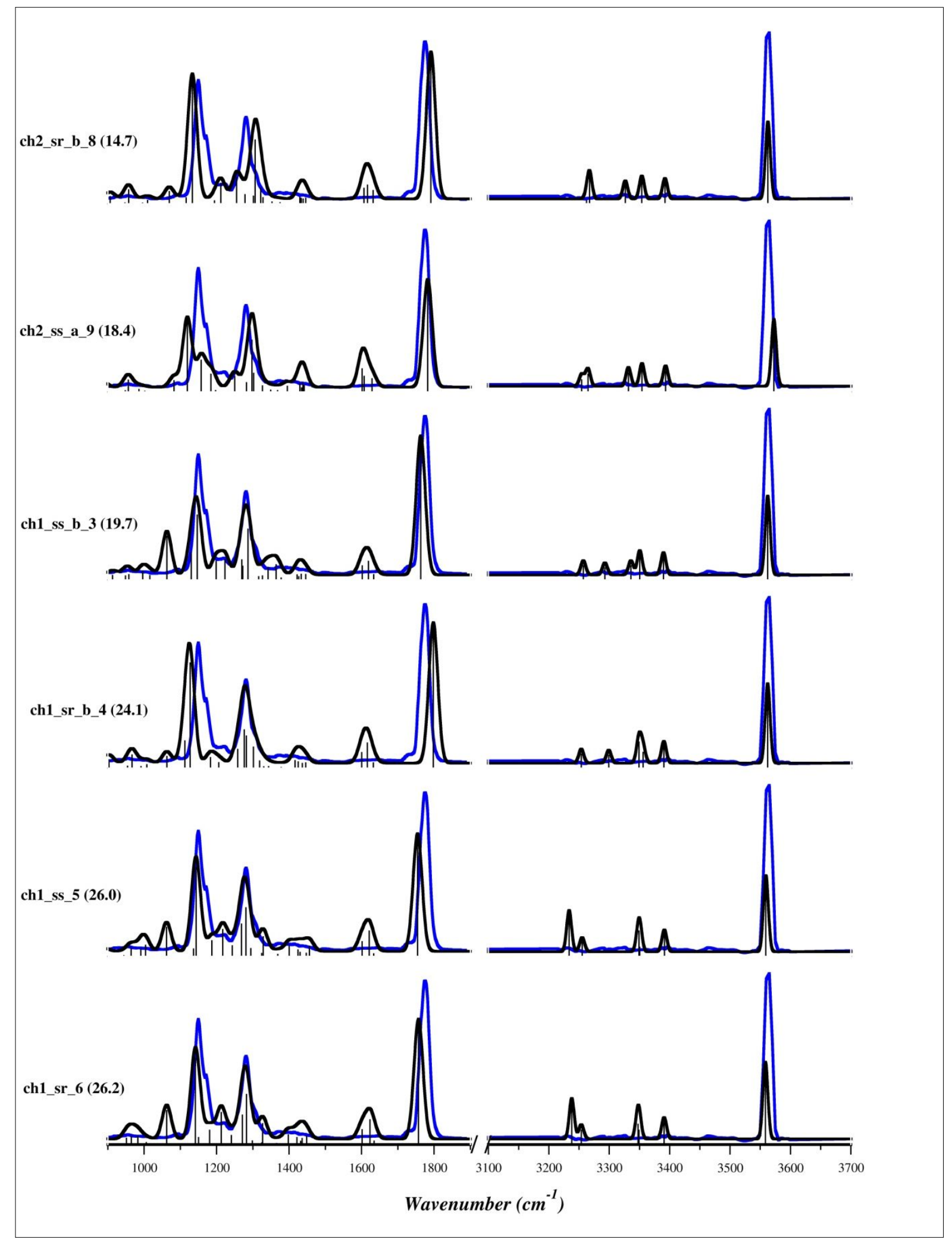

Figure S6 (continuation). IRMPD spectrum of $\left[\mathrm{PtCl}\left(\mathrm{NH}_{3}\right)(\mathrm{Met})\right]^{+}$(blue profile) compared with the calculated IR spectra (black profiles) of the lowest lying conformers of the ch1 and ch2 families, computed at B3LYP/BS1 level of theory. Theoretical frequencies have been scaled by 0.974 and 0.957 in the $900-1900 \mathrm{~cm}^{-1}$ and the $3100-3700 \mathrm{~cm}^{-1}$ ranges, respectively. Free energies relative to ch2_ss_b_1 are reported in brackets $\left(\mathrm{kJ} \mathrm{mol}^{-1}\right)$. 


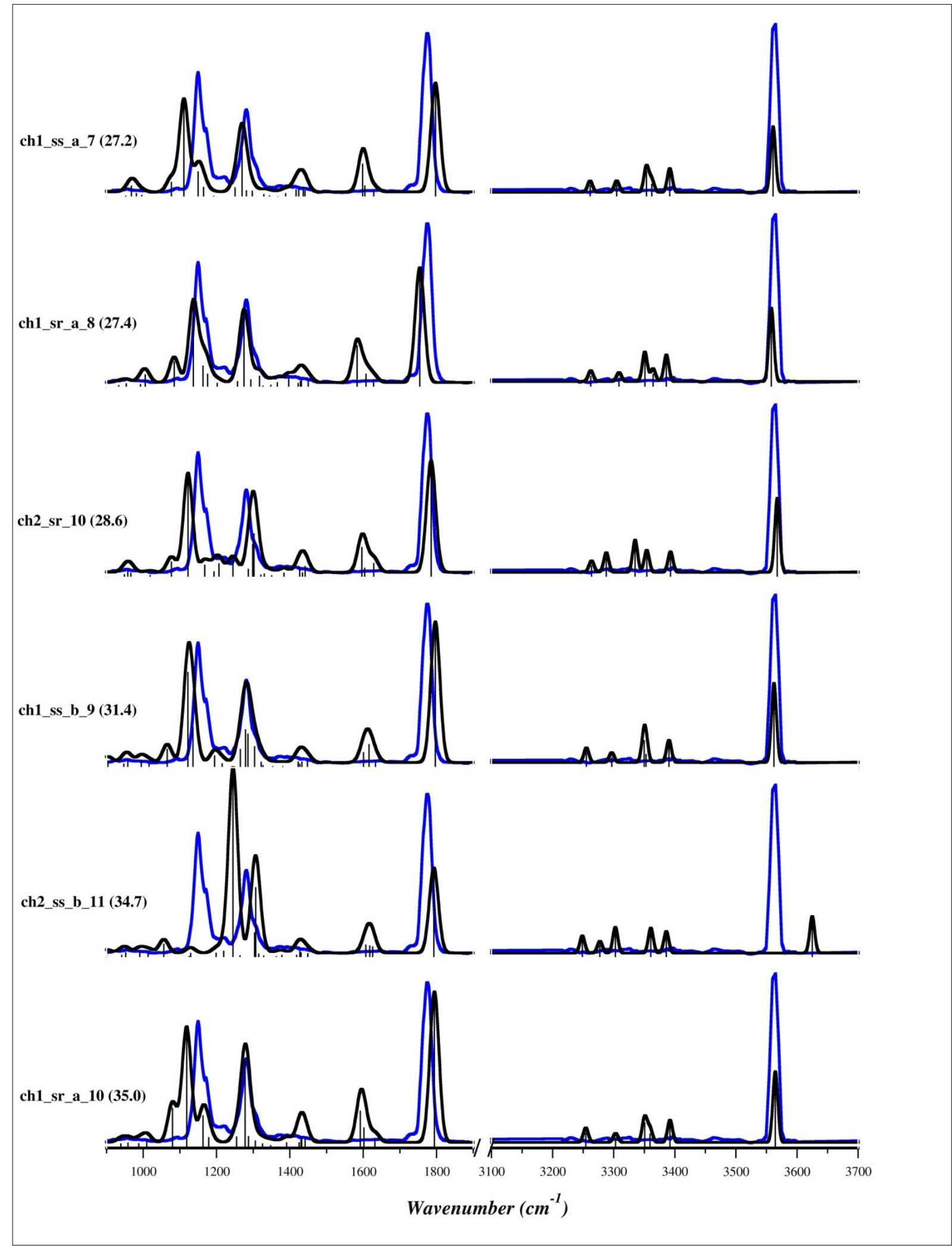

Figure S6 (continuation). IRMPD spectrum of $\left[\mathrm{PtCl}\left(\mathrm{NH}_{3}\right)(\mathrm{Met})\right]^{+}$(blue profile) compared with the calculated IR spectra (black profiles) of the lowest lying conformers of the ch1 and ch2 families, computed at B3LYP/BS1 level of theory. Theoretical frequencies have been scaled by 0.974 and 0.957 in the $900-1900 \mathrm{~cm}^{-1}$ and the $3100-3700 \mathrm{~cm}^{-1}$ ranges, respectively. Free energies relative to ch2_ss_b_1 are reported in brackets $\left(\mathrm{kJ} \mathrm{mol}^{-1}\right)$. 


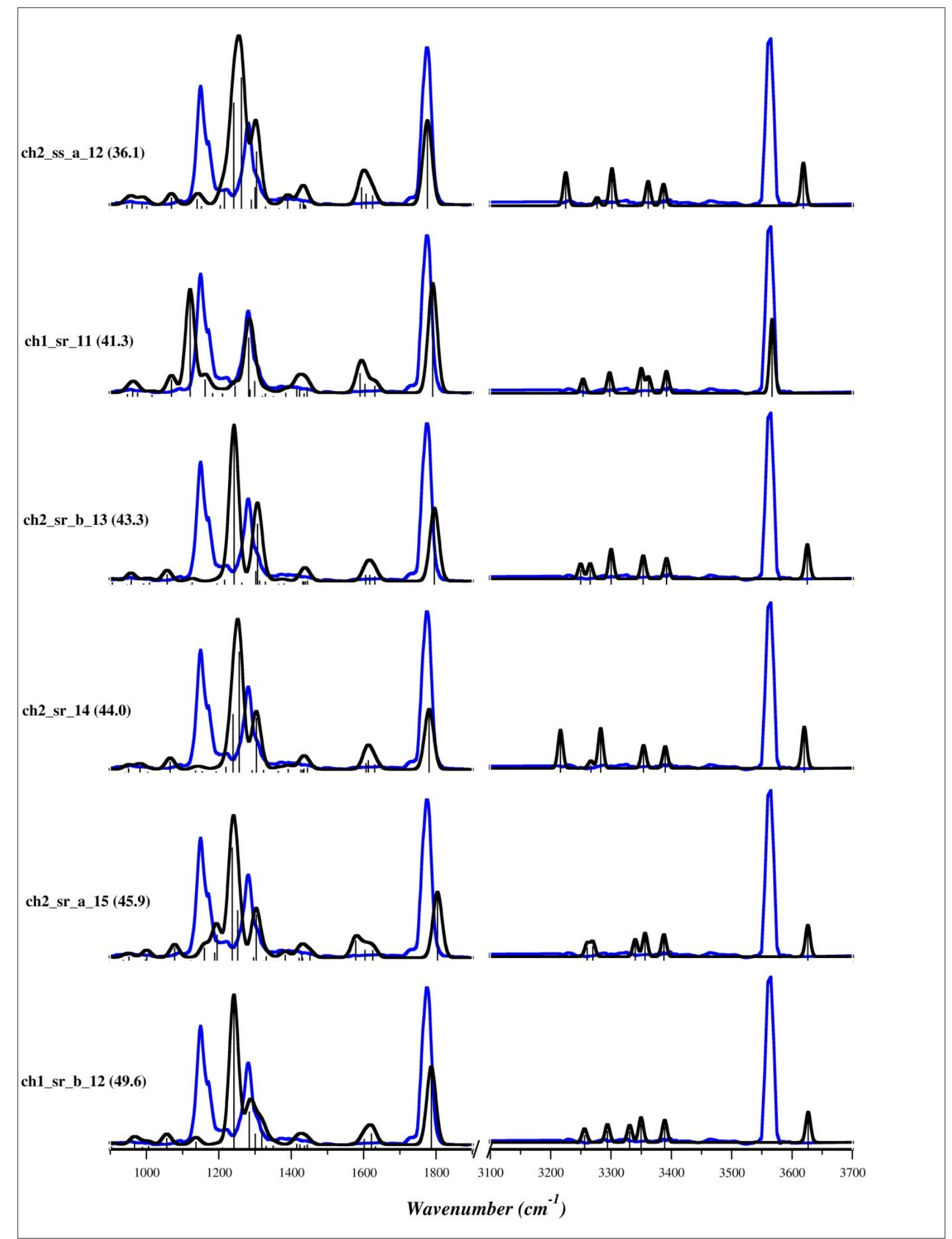

Figure S6 (continuation). IRMPD spectrum of $\left[\mathrm{PtCl}\left(\mathrm{NH}_{3}\right)(\mathrm{Met})\right]^{+}$(blue profile) compared with the calculated IR spectra (black profiles) of the lowest lying conformers of the ch1 and ch2 families, computed at B3LYP/BS1 level of theory. Theoretical frequencies have been scaled by 0.974 and 0.957 in the $900-1900 \mathrm{~cm}^{-1}$ and the $3100-3700 \mathrm{~cm}^{-1}$ ranges, respectively. Free energies relative to ch2_ss_b_1 are reported in brackets $\left(\mathrm{kJ} \mathrm{mol}^{-1}\right)$. 


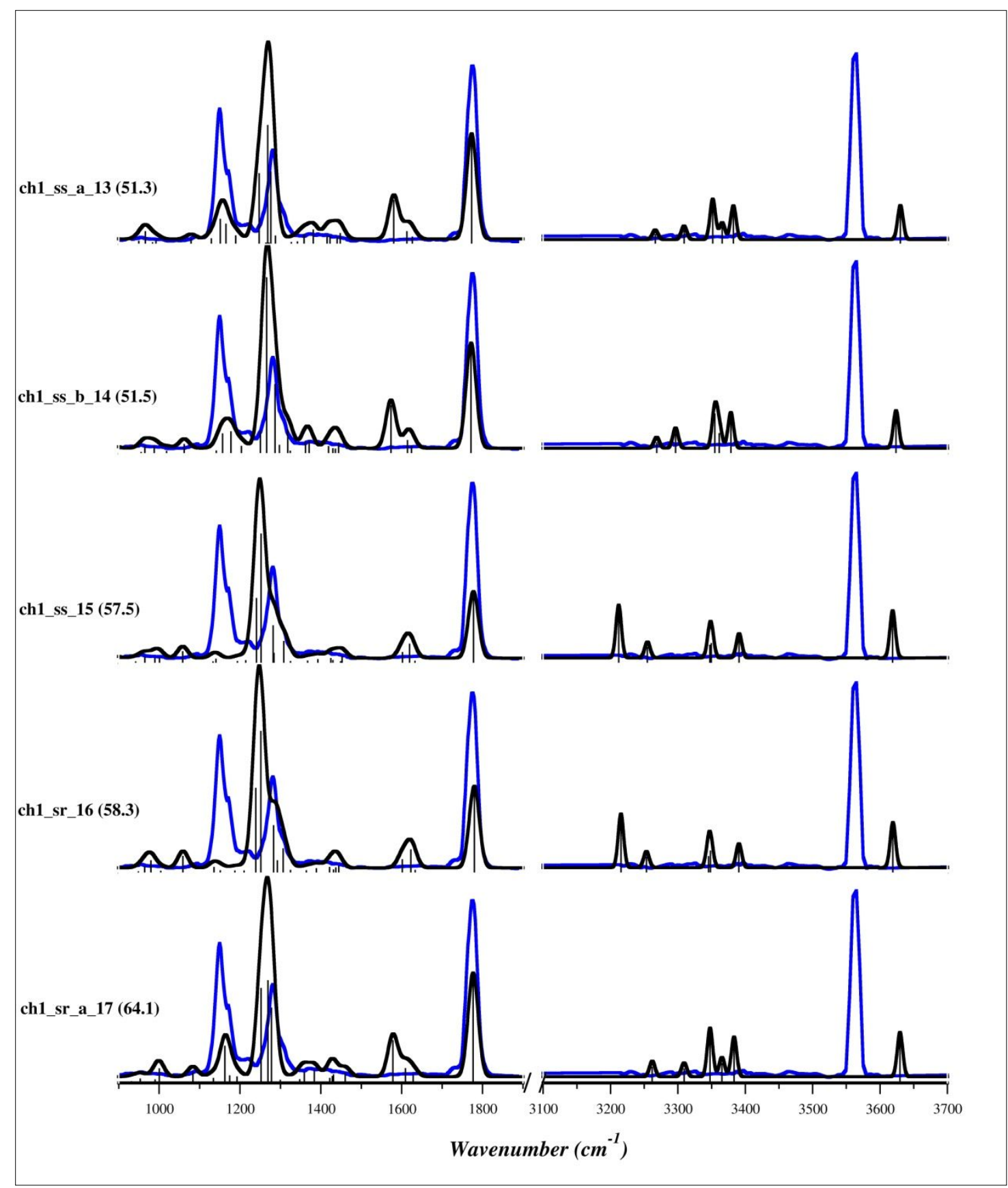

Figure S6 (continuation). IRMPD spectrum of $\left[\mathrm{PtCl}\left(\mathrm{NH}_{3}\right)(\mathrm{Met})\right]^{+}$(blue profile) compared with the calculated IR spectra (black profiles) of the lowest lying conformers of the ch1 and ch2 families, computed at B3LYP/BS1 level of theory. Theoretical frequencies have been scaled by 0.974 and 0.957 in the $900-1900 \mathrm{~cm}^{-1}$ and the $3100-3700 \mathrm{~cm}^{-1}$ ranges, respectively. Free energies relative to ch2_ss_b_1 are reported in brackets $\left(\mathrm{kJ} \mathrm{mol}^{-1}\right)$. 


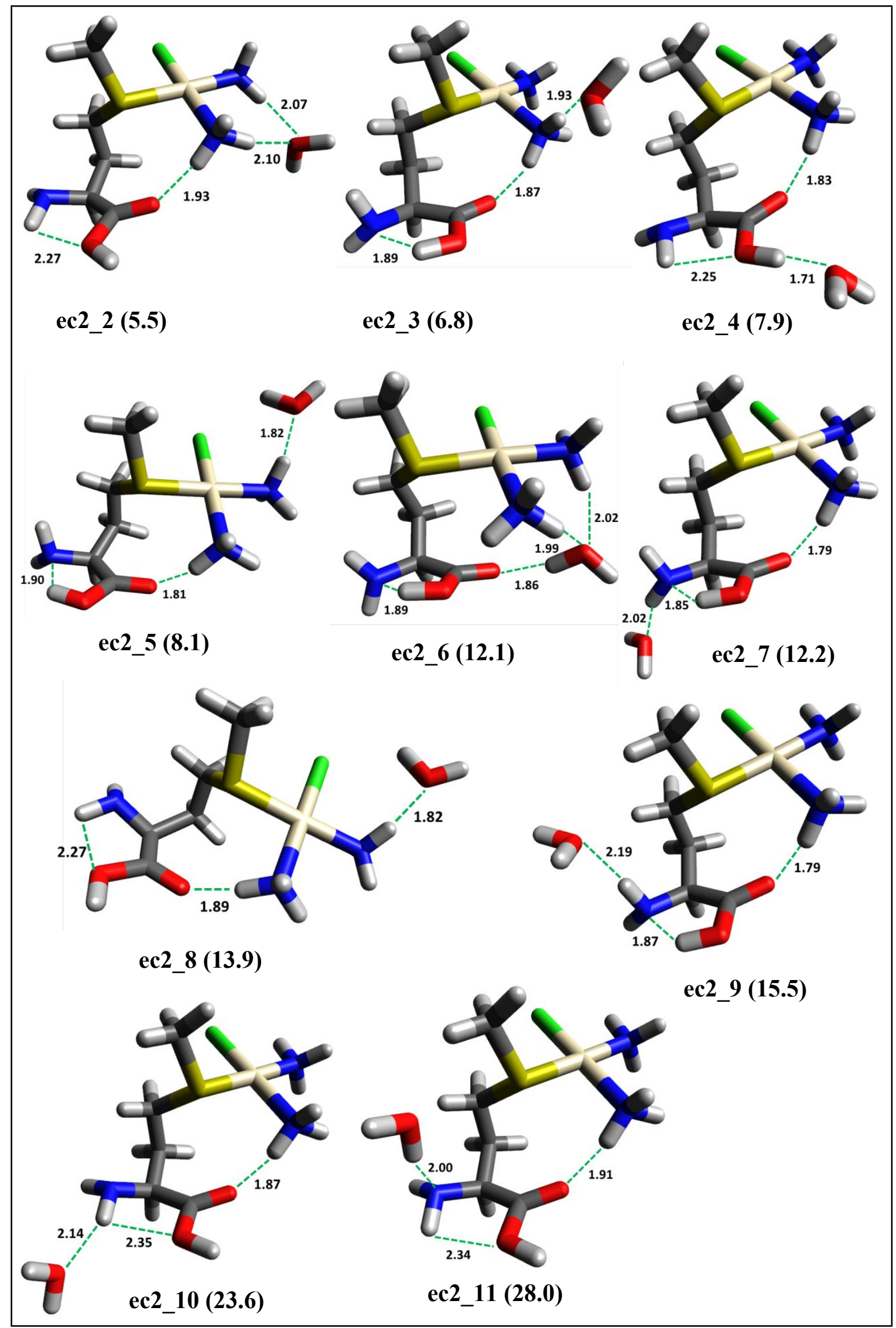

Figure S7. Optimized geometries for ec2 isomers, \{cis-[PtCl( $\left.\left.\left(\mathrm{NH}_{3}\right)_{2} \mathrm{Met}\right]^{+} \bullet \mathrm{H}_{2} \mathrm{O}\right\}$. Relative Gibbs energy values $\left(\mathrm{kJ} \mathrm{mol}^{-1}\right)$ are reported in parenthesis. Hydrogen bond distances $(\AA)$ are indicated by green dashed lines. 


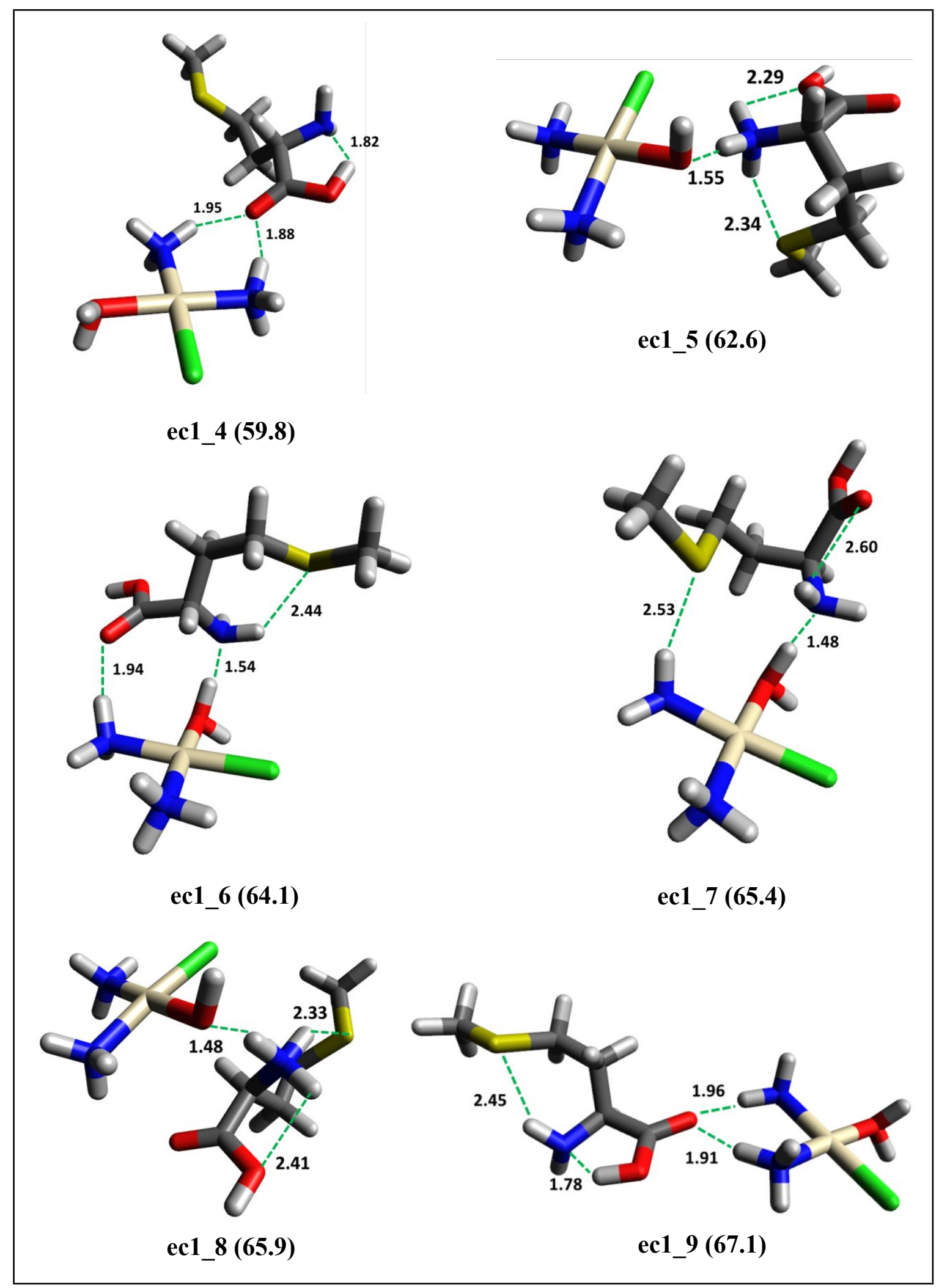

Figure S8. Optimized geometries for ec1 isomers, \{cis-[PtCl$\left.\left(\mathrm{NH}_{3}\right)_{2}\left(\mathrm{H}_{2} \mathrm{O}\right)\right]^{+} \bullet$ Met $\}$ and \{cis$\left.\left[\mathrm{PtCl}\left(\mathrm{NH}_{3}\right)_{2}(\mathrm{OH})\right] \bullet \mathrm{MetH}^{+}\right\}$. Relative Gibbs energy values $\left(\mathrm{kJ} \mathrm{mol}^{-1}\right)$ are reported in parenthesis. Hydrogen bond distances $(\AA)$ are indicated by green dashed lines. 


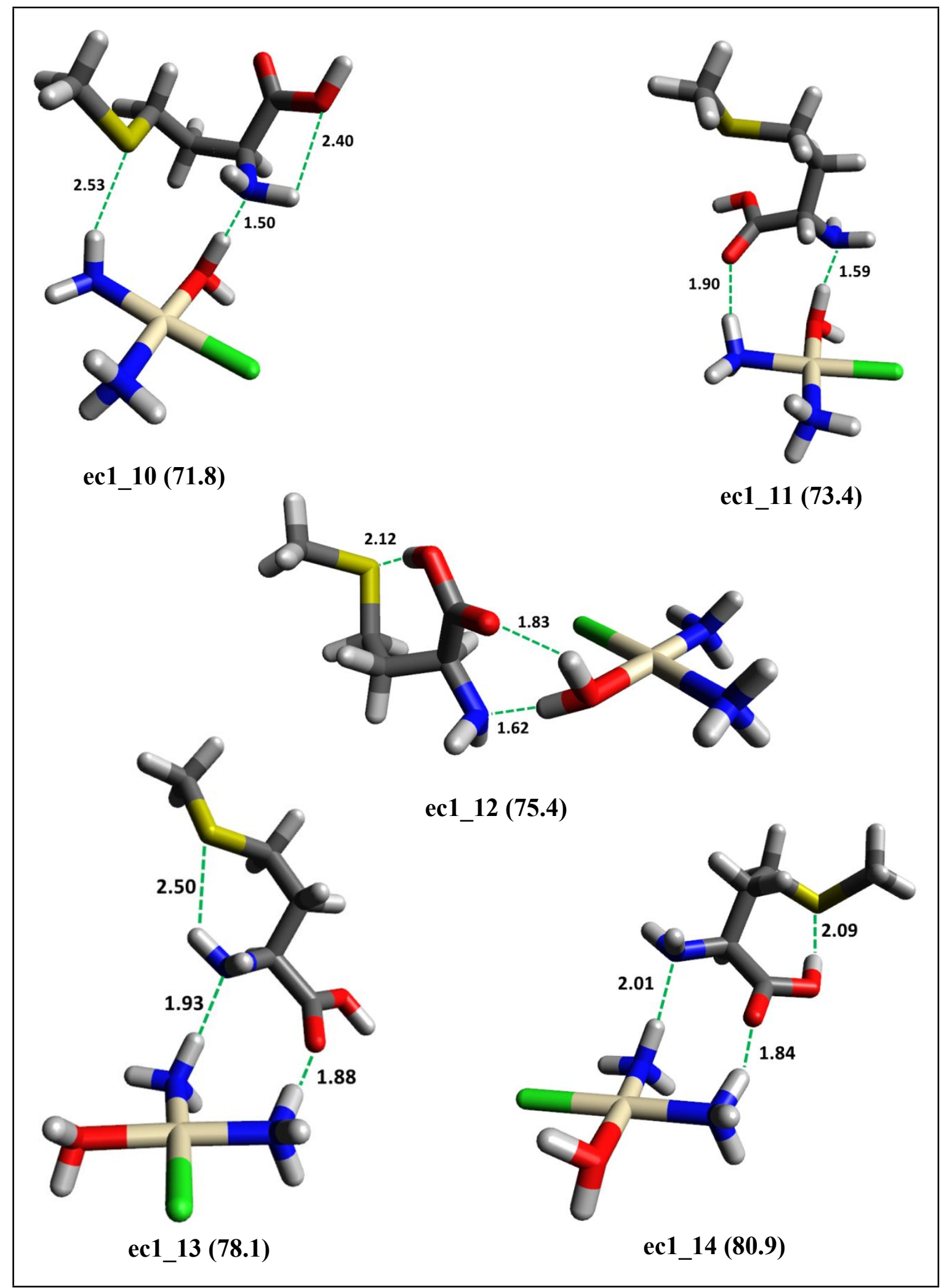

Figure S8 (continuation). Optimized geometries for ec1 isomers, $\left\{\right.$ cis- $\left[\mathrm{PtCl}\left(\mathrm{NH}_{3}\right)_{2}\left(\mathrm{H}_{2} \mathrm{O}\right)\right]^{+} \bullet$ Met $\}$. Relative Gibbs energy values $\left(\mathrm{kJ} \mathrm{mol}^{-1}\right)$ are reported in parenthesis. Hydrogen bond distances $(\AA)$ are indicated by green dashed lines. 


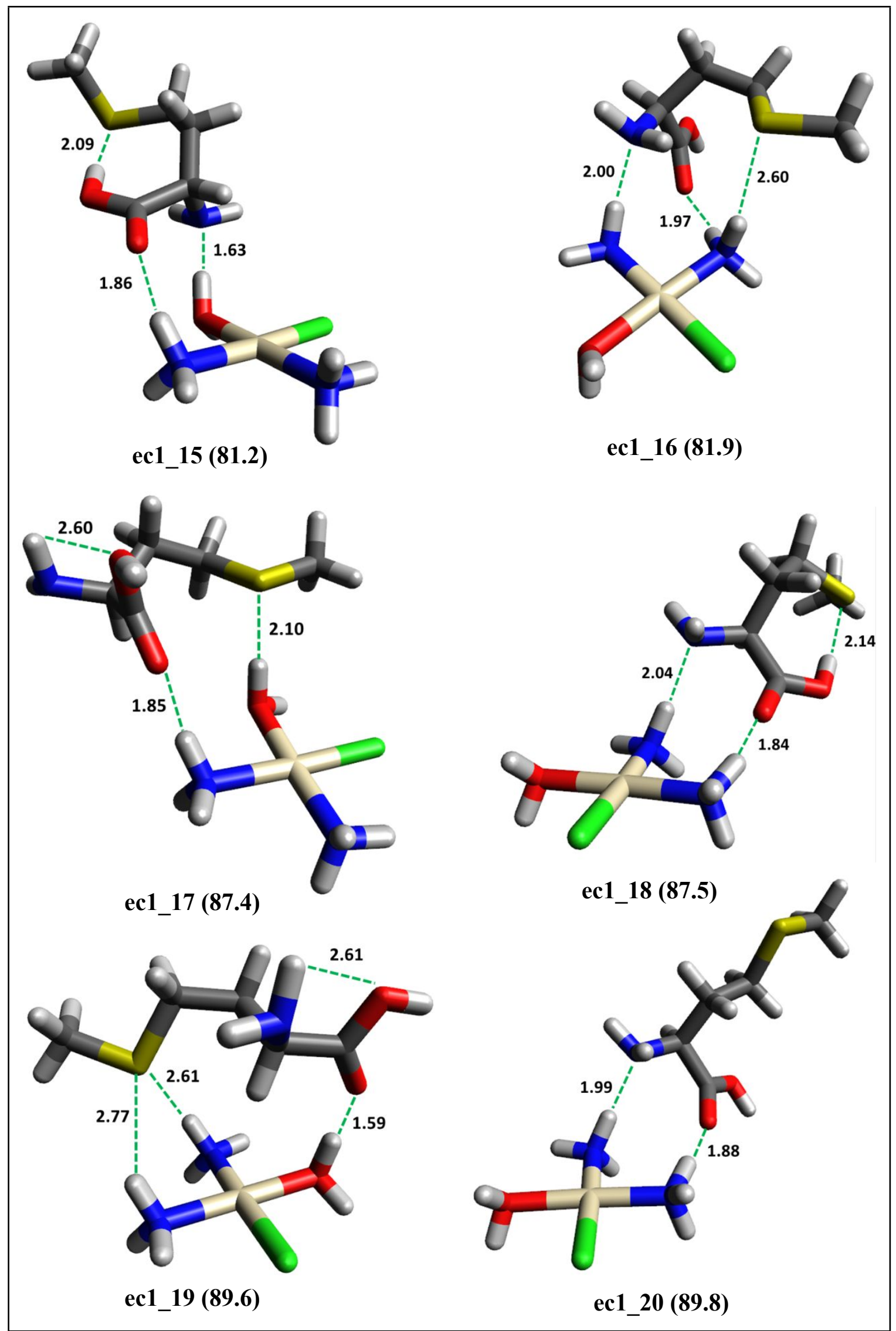

Figure S8 (continuation). Optimized geometries for ec1 isomers, $\left\{\right.$ cis- $\left[\mathrm{PtCl}\left(\mathrm{NH}_{3}\right)_{2}\left(\mathrm{H}_{2} \mathrm{O}\right)\right]^{+} \bullet$ Met $\}$. Relative Gibbs energy values $\left(\mathrm{kJ} \mathrm{mol}^{-1}\right)$ are reported in parenthesis. Hydrogen bond distances $(\AA)$ are indicated by green dashed lines. 


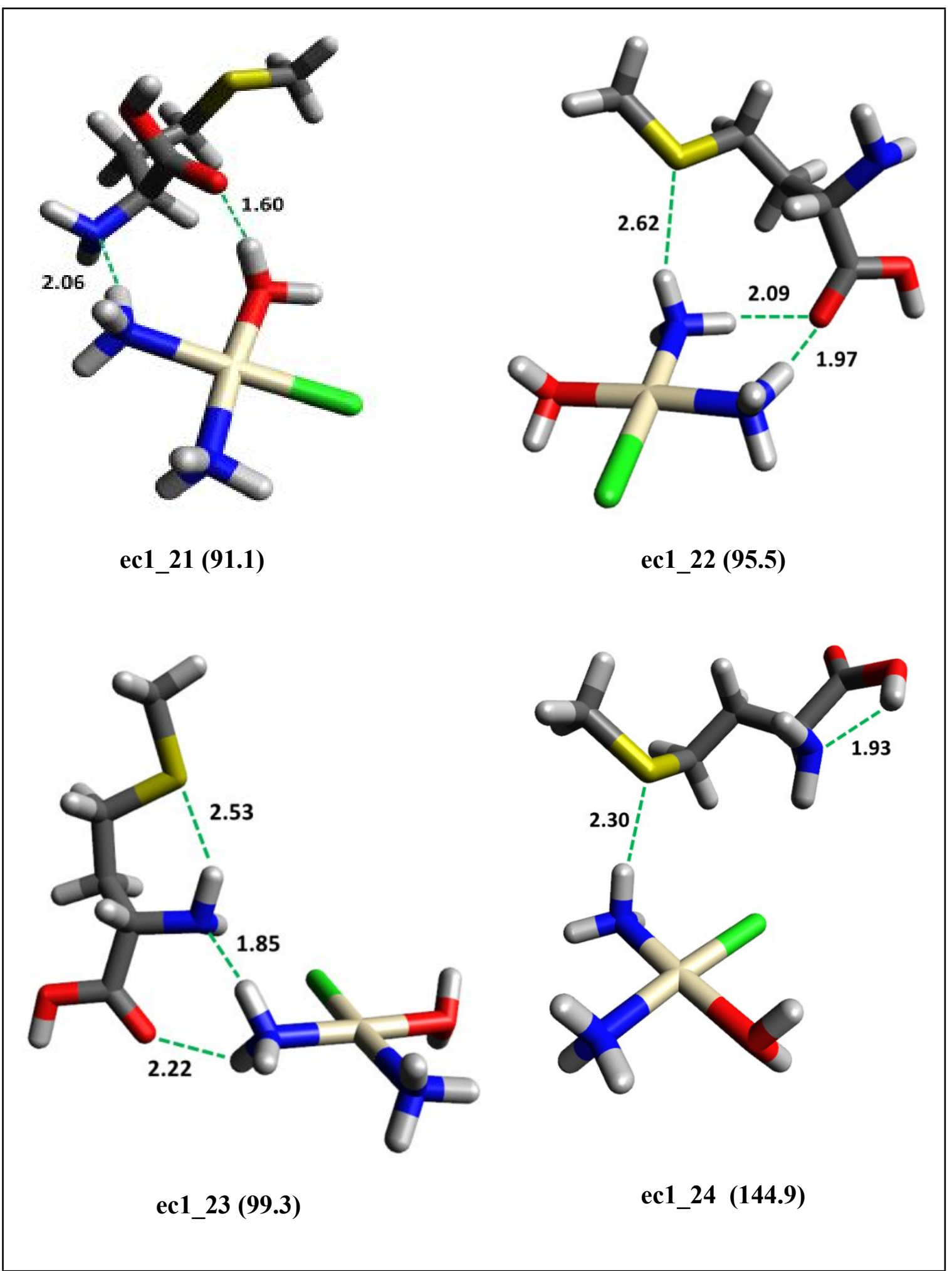

Figure S8 (continuation). Optimized geometries for ec1 isomers, $\left\{\right.$ cis- $\left[\mathrm{PtCl}\left(\mathrm{NH}_{3}\right)_{2}\left(\mathrm{H}_{2} \mathrm{O}\right)\right]^{+} \bullet$ Met . Relative Gibbs energy values $\left(\mathrm{kJ} \mathrm{mol}^{-1}\right)$ are reported in parenthesis. Hydrogen bond distances $(\AA \AA)$ are indicated by green dashed lines. 


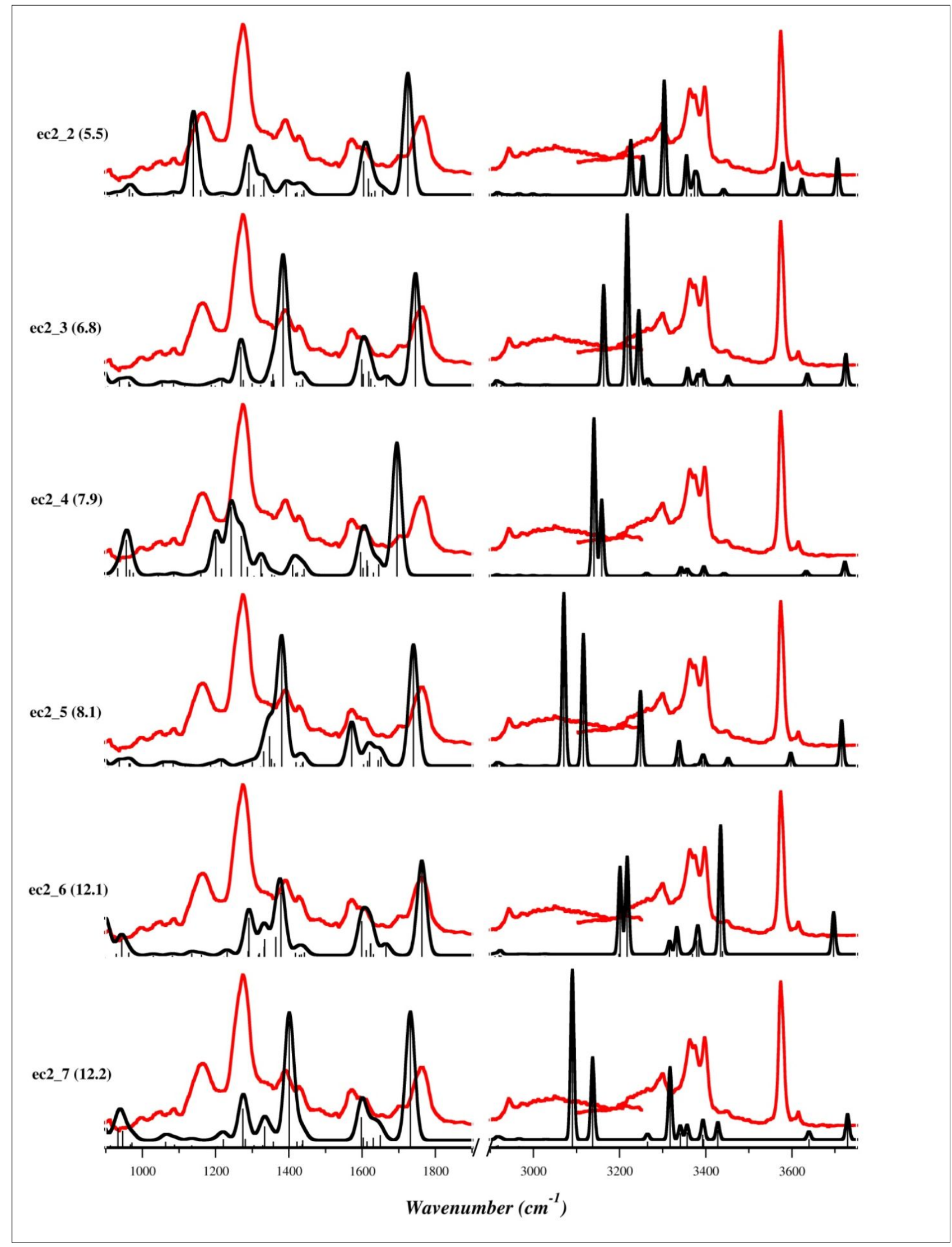

Figure S9. IRMPD spectrum of $\left[\mathrm{PtCl}\left(\mathrm{NH}_{3}\right)_{2}\left(\mathrm{H}_{2} \mathrm{O}\right)(\mathrm{Met})\right]^{+}$(red profile) compared with the calculated IR spectra (black profiles) of the lowest lying geometries of the ec2 and ec1 isomer families, computed at B3LYP/BS1 level of theory. Theoretical frequencies have been scaled by 0.974 and 0.957 in the $900-1900 \mathrm{~cm}^{-1}$ and the $3000-3700 \mathrm{~cm}^{-1}$ ranges, respectively. Free energies relative to ec2_1 are reported in brackets $\left(\mathrm{kJ} \mathrm{mol}^{-1}\right)$. 


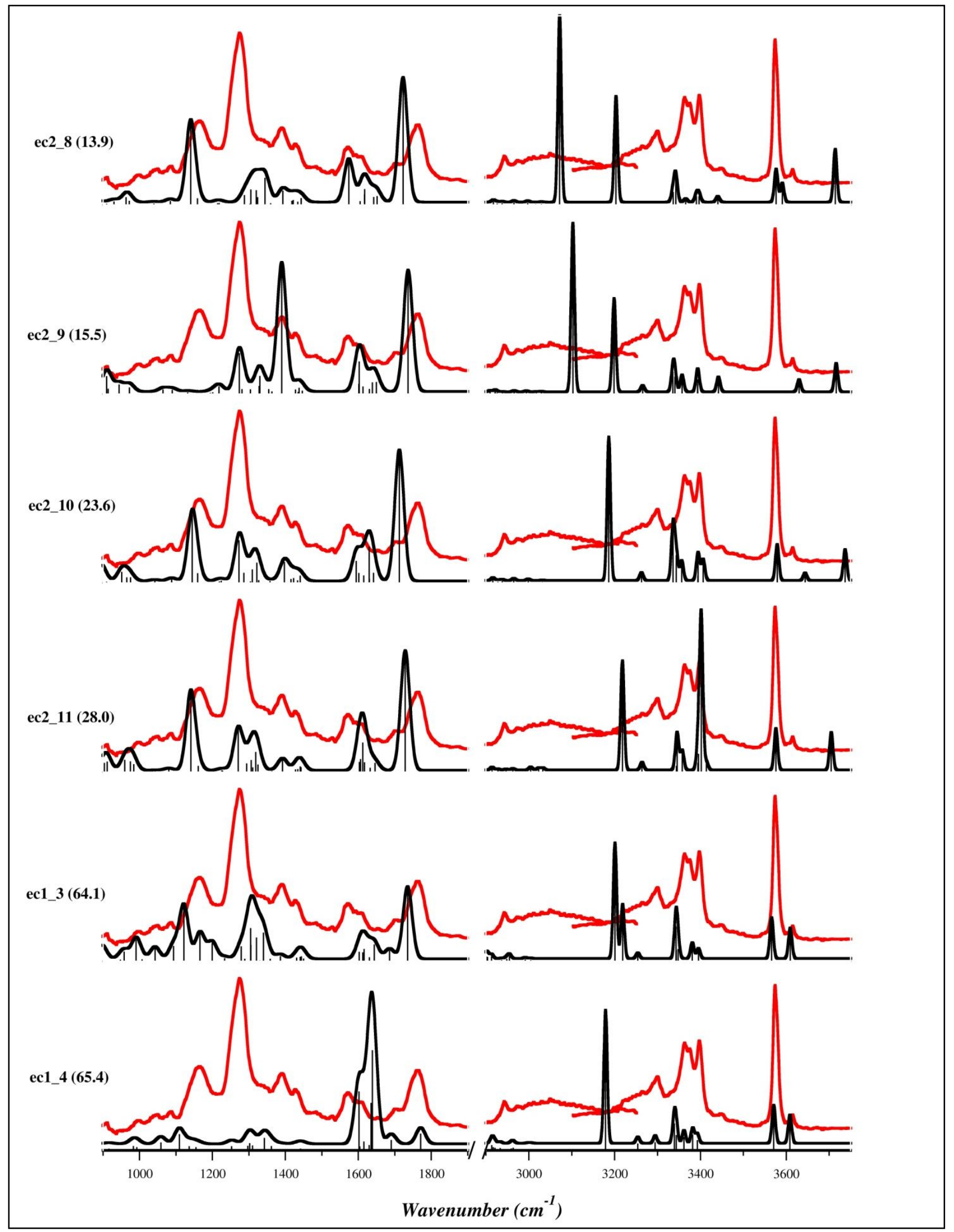

Figure S9 (continuation). IRMPD spectrum of $\left[\mathrm{PtCl}\left(\mathrm{NH}_{3}\right)_{2}\left(\mathrm{H}_{2} \mathrm{O}\right)(\mathrm{Met})\right]^{+}$(red profile) compared with the calculated IR spectra (black profiles) of the lowest lying geometries of the ec2 and ec1 isomer families, computed at B3LYP/BS1 level of theory. Theoretical frequencies have been scaled by 0.974 and 0.957 in the $900-1900 \mathrm{~cm}^{-1}$ and the $3000-3700 \mathrm{~cm}^{-1}$ ranges, respectively. Free energies relative to ec2_1 are reported in brackets $\left(\mathrm{kJ} \mathrm{mol}^{-1}\right)$. 


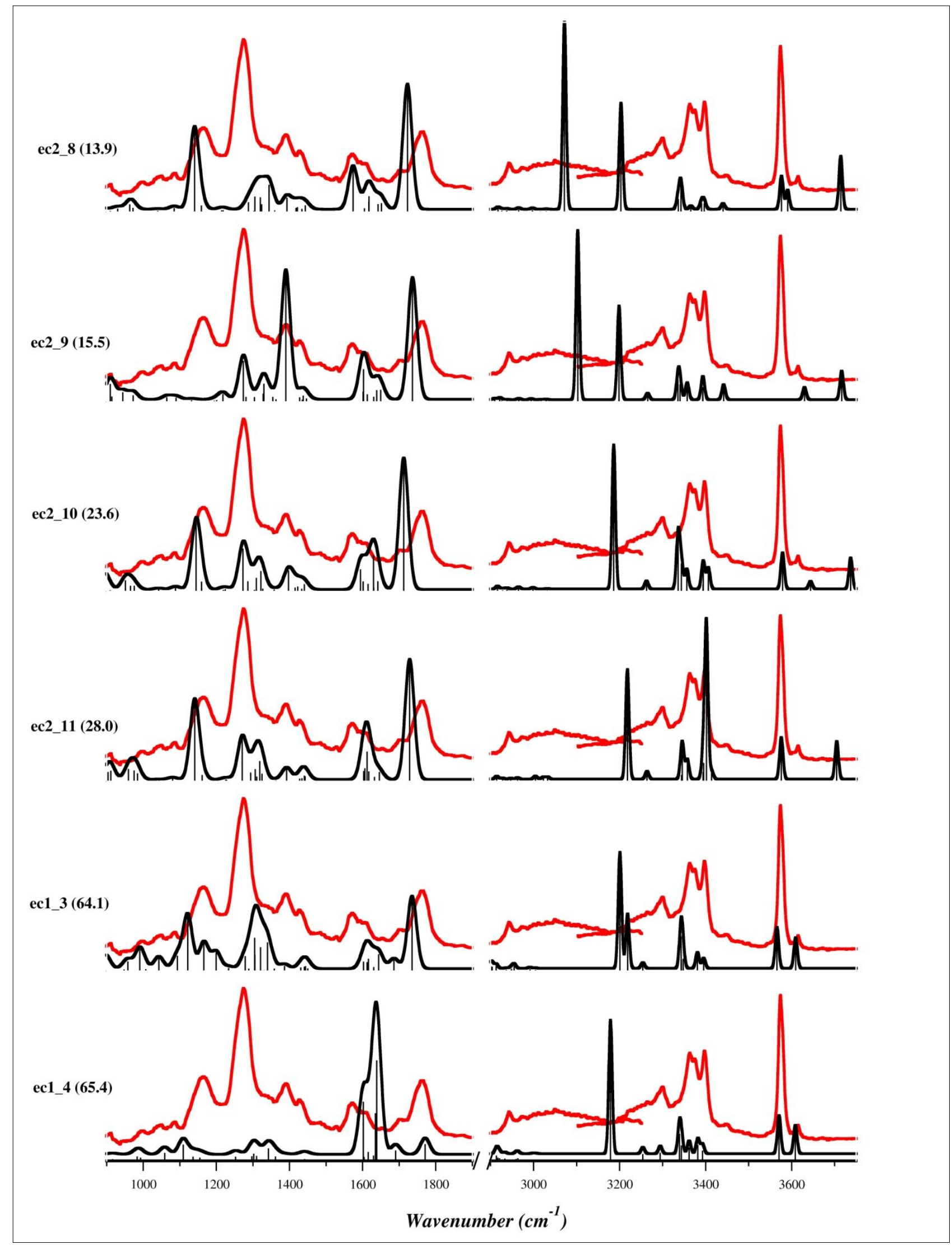

Figure S9 (continuation). IRMPD spectrum of $\left[\mathrm{PtCl}\left(\mathrm{NH}_{3}\right)_{2}\left(\mathrm{H}_{2} \mathrm{O}\right)(\mathrm{Met})\right]^{+}$(red profile) compared with the calculated IR spectra (black profiles) of the lowest lying geometries of the ec2 and ec1 isomer families, computed at B3LYP/BS1 level of theory. Theoretical frequencies have been scaled by 0.974 and 0.957 in the $900-1900 \mathrm{~cm}^{-1}$ and the $3000-3700 \mathrm{~cm}^{-1}$ ranges, respectively. Free energies relative to ec2_1 are reported in brackets $\left(\mathrm{kJ} \mathrm{mol}^{-1}\right)$. 


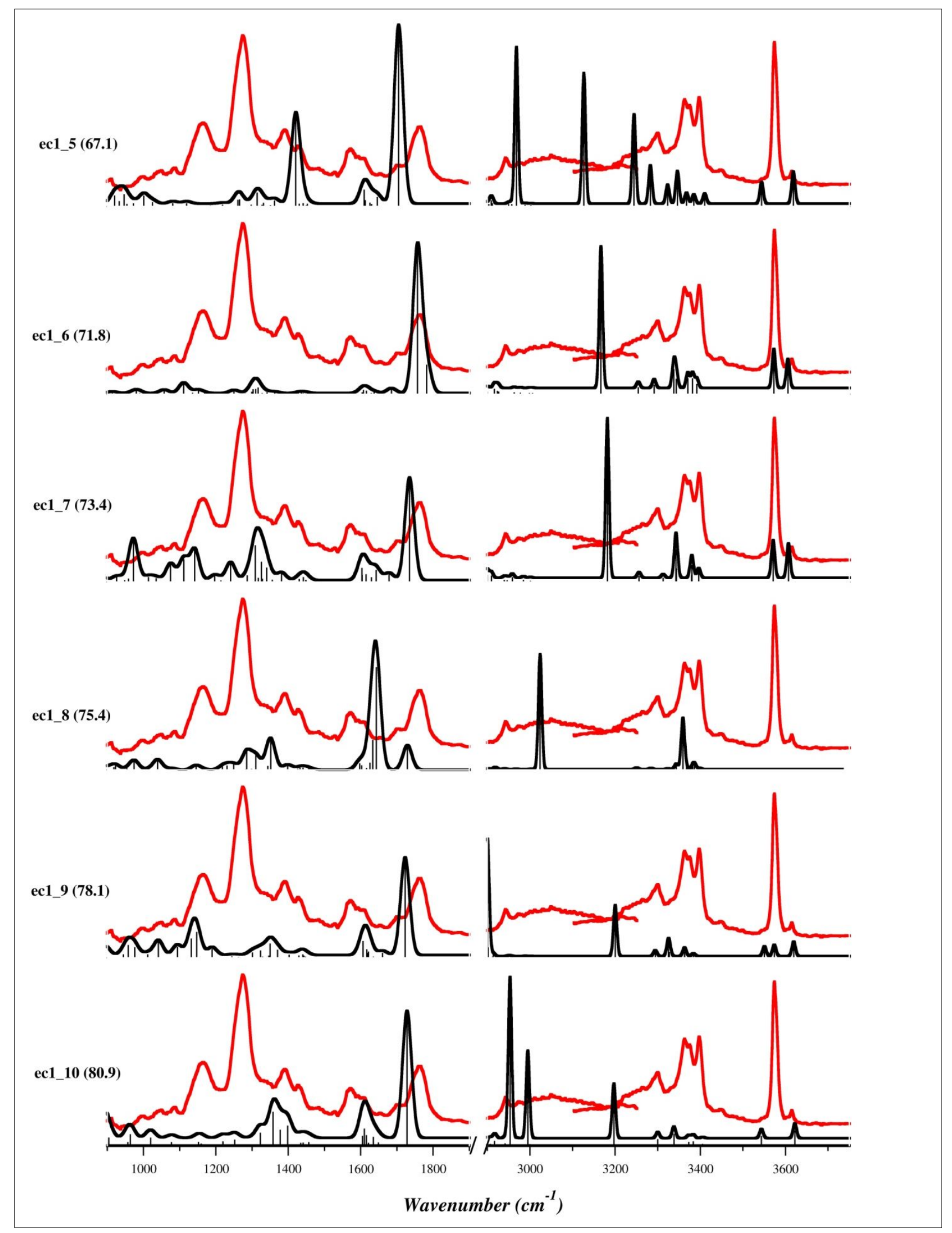

Figure S9 (continuation). IRMPD spectrum of $\left[\mathrm{PtCl}\left(\mathrm{NH}_{3}\right)_{2}\left(\mathrm{H}_{2} \mathrm{O}\right)(\mathrm{Met})\right]^{+}$(red profile) compared with the calculated IR spectra (black profiles) of the lowest lying geometries of the ec2 and ec1 isomer families, computed at B3LYP/BS1 level of theory. Theoretical frequencies have been scaled by 0.974 and 0.957 in the $900-1900 \mathrm{~cm}^{-1}$ and the $3000-3700 \mathrm{~cm}^{-1}$ ranges, respectively. Free energies relative to ec2_1 are reported in brackets $\left(\mathrm{kJ} \mathrm{mol}^{-1}\right)$. 


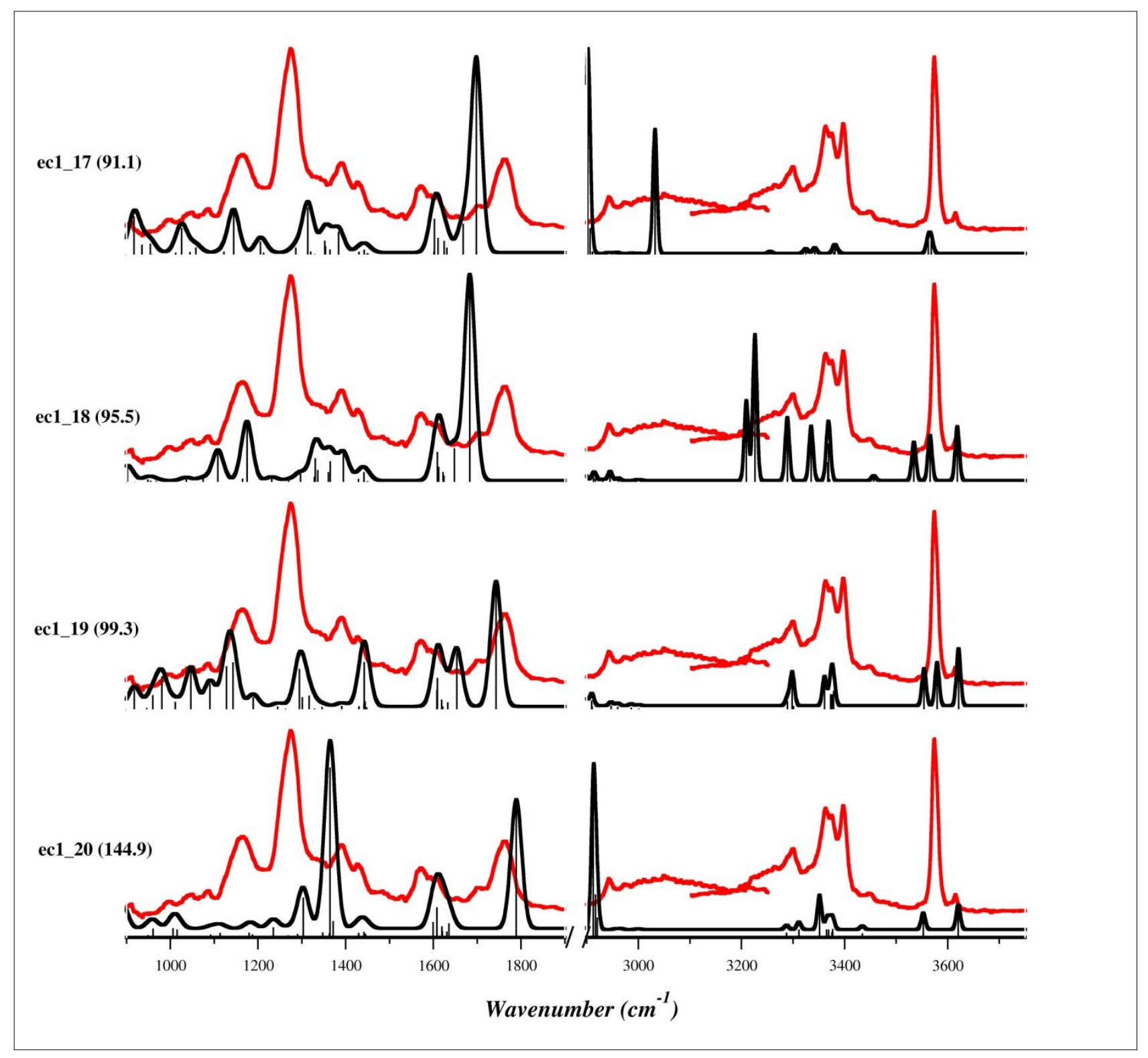

Figure S9 (continuation). IRMPD spectrum of $\left[\mathrm{PtCl}\left(\mathrm{NH}_{3}\right)_{2}\left(\mathrm{H}_{2} \mathrm{O}\right) \text { (Met) }\right]^{+}$(red profile) compared with the calculated IR spectra (black profiles) of the lowest lying geometries of the ec2 and ec1 isomer families, computed at B3LYP/BS1 level of theory. Theoretical frequencies have been scaled by 0.974 and 0.957 in the $900-1900 \mathrm{~cm}^{-1}$ and the $3000-3700 \mathrm{~cm}^{-1}$ ranges, respectively. Free energies relative to ec2_1 are reported in brackets $\left(\mathrm{kJ} \mathrm{mol}^{-1}\right)$. 


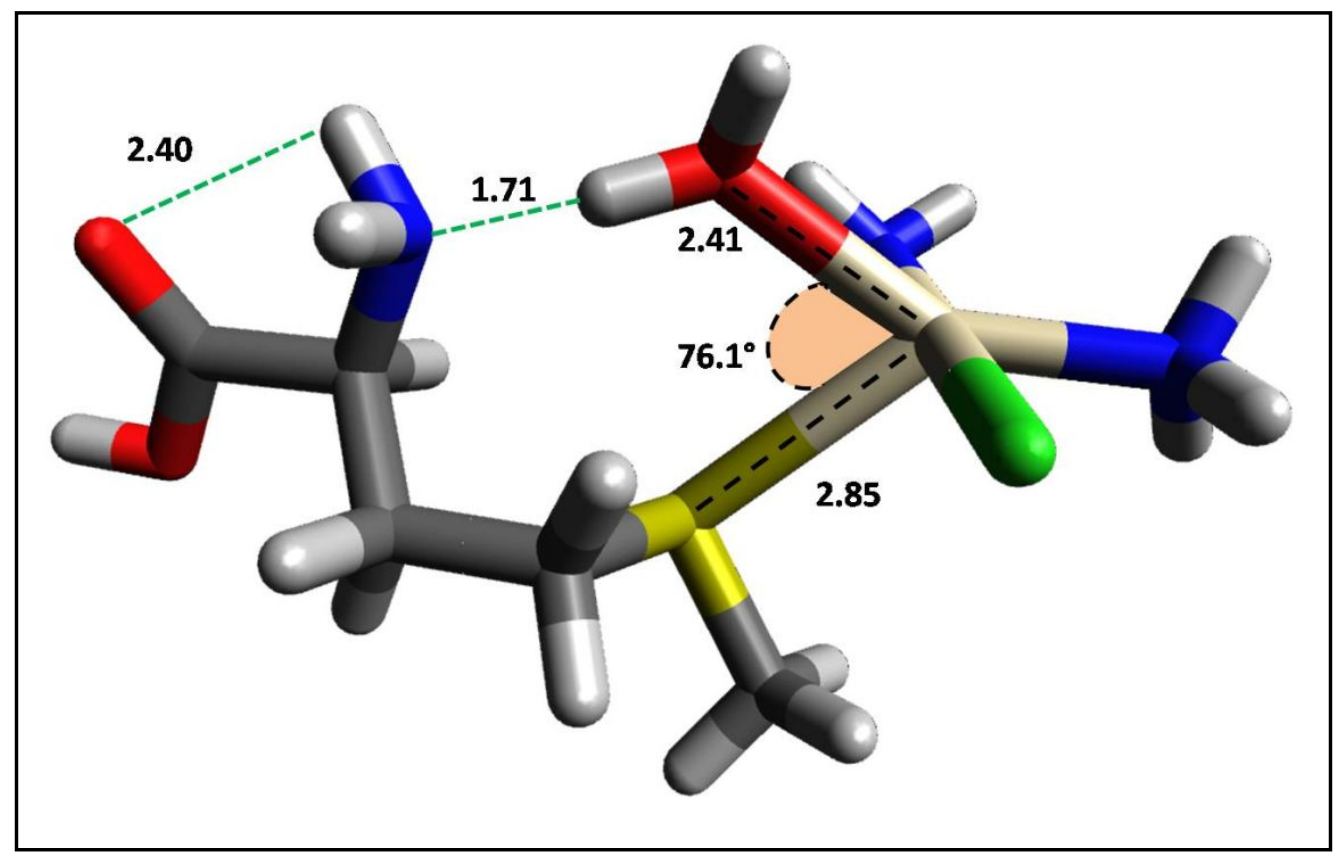

Figure S10: Structure of transition state participating in the reaction pathway for the ligand substitution reaction of cis-[PtCl$\left.\left(\mathrm{NH}_{3}\right)_{2}\left(\mathrm{H}_{2} \mathrm{O}\right)\right]^{+}$with Met. Bond lengths are in $\AA$. The structural motives characterizing the only negative vibrational frequency are highlighted by the black dashed lines while $\mathrm{H}$ bonds are reported as green dashed lines.

A)

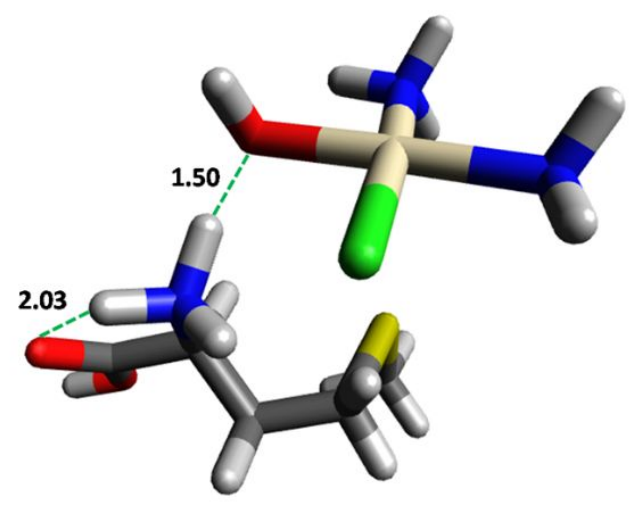

IRC - reactant (58.6)
B)

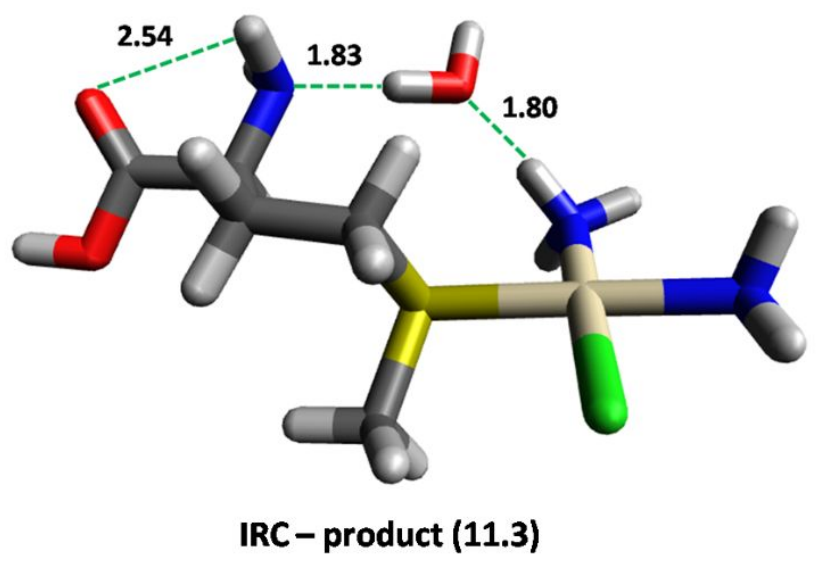

Figure S11: Optimized geometries of the reactant $(A)$ and of the product $(B)$ obtained by intrinsic

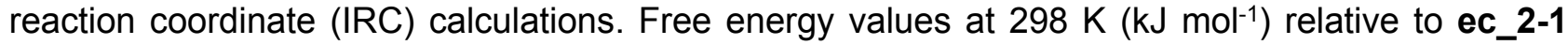
are shown in brackets. The hydrogen bond $(\AA)$ lengths are indicated by green dashed lines. 
Table S1. IRMPD absorptions of $\left[\mathrm{PtCl}\left(\mathrm{NH}_{3}\right)(\mathrm{Met})\right]^{+}$ions and calculated vibrational frequencies $\left(\mathrm{cm}^{-}\right.$ 1) for ch1_sr_b_1 and ch1_ss_a_2. Calculated intensities are reported in brackets $\left(\mathrm{km} \mathrm{mol}^{-1}\right)$. Modes with intensity lower than $15 \mathrm{~km} \mathrm{~mol}^{-1}$ are omitted.

\begin{tabular}{|c|c|c|c|}
\hline \multicolumn{2}{|c|}{ Calculated $^{\#}$} & \multirow{2}{*}{$\begin{array}{c}\operatorname{Exp} \\
{\left[\mathrm{PtCl}\left(\mathrm{NH}_{3}\right)(\mathrm{Met})\right]^{+}}\end{array}$} & \multirow[t]{2}{*}{ Vibrational mode } \\
\hline ch1_sr_b_1 & ch1_ss_a_2 & & \\
\hline $967^{\mathrm{a}}(28)$ & & 960 & $\mathrm{CH}_{3}$ asymm bending \\
\hline $1062^{\mathrm{a}}(77)$ & $1080^{\mathrm{a}}(33)$ & 1090 & $\begin{array}{c}\mathrm{CN} \text { stretching }+\mathrm{CC} \text { stretching }+ \\
\mathrm{OH} \text { bending }\end{array}$ \\
\hline \multirow[t]{3}{*}{$1150^{\mathrm{a}}(178)$} & $1129^{a}(133)$ & 1148 & $\mathrm{OH}$ bending $+\mathrm{CH}_{2}$ scissoring \\
\hline & $1161^{\mathrm{a}}(56)$ & 1175 (shoulder) & $\begin{array}{c}\mathrm{OH} \text { bending }+\mathrm{NH}_{2} \text { wagging }+ \\
\mathrm{CH}_{2} \text { twisting }\end{array}$ \\
\hline & $1163^{\mathrm{a}}(63)$ & & $\mathrm{OH}$ bending $+\mathrm{NH}_{2}$ wagging \\
\hline $1190^{\mathrm{a}}(36)$ & & & $\begin{array}{c}\mathrm{NH}_{2} \text { wagging }+\mathrm{CH}_{2} \text { twisting }+ \\
\mathrm{CH} \text { bending }\end{array}$ \\
\hline $1210^{\mathrm{a}}(56)$ & & 1222 & $\mathrm{NH}_{2}$ wagging $+\mathrm{CH}_{2}$ twisting \\
\hline $1260^{\mathrm{a}}(30)$ & & & $\mathrm{CH}_{2}$ wagging $+\mathrm{NH}_{2}$ twisting \\
\hline $1271^{\mathrm{a}}(34)$ & & & $\mathrm{CH}$ bending $+\mathrm{OH}$ bending \\
\hline $1282^{\mathrm{a}}(111)$ & $1273^{a}(142)$ & 1280 & $\mathrm{NH}_{3}$ umbrella mode \\
\hline $1360^{\mathrm{a}}(52)$ & & 1390 & $\mathrm{CH}$ bending $+\mathrm{C}-\mathrm{OH}$ bending \\
\hline $1601^{\mathrm{a}}(32)$ & & 1620 & $\mathrm{NH}_{3}$ asymm bending \\
\hline $1621^{\mathrm{a}}(51)$ & $1585^{\mathrm{a}}(91)$ & & $\begin{array}{c}\mathrm{NH}_{2} \text { scissoring }+\mathrm{NH}_{3} \text { asymm } \\
\text { bending }\end{array}$ \\
\hline $1760^{\mathrm{a}}(294)$ & $1750^{\mathrm{a}}(245)$ & 1777 & $\mathrm{C}=\mathrm{O}$ stretching \\
\hline $3256^{\mathrm{b}}(28)$ & & & $\mathrm{NH}_{3}$ symm stretching \\
\hline $3287^{\mathrm{b}}(42)$ & $3309^{\mathrm{b}}(25)$ & & $\mathrm{NH}_{2}$ symm stretching \\
\hline $3326^{\mathrm{b}}(38)$ & & & $\mathrm{NH}_{2}$ asymm stretching \\
\hline $3351^{\mathrm{b}}(52)$ & $3353^{\mathrm{b}}(70)$ & & $\mathrm{NH}_{3}$ asymm stretching \\
\hline & $3365^{\mathrm{b}}(31)$ & & $\mathrm{NH}_{2}$ asymm stretching \\
\hline
\end{tabular}


\#Theoretical IR frequencies were computed at B3LYP/BS1 level of theory.

a Frequencies are scaled by a factor of 0.974 .

${ }^{b}$ Frequencies are scaled by a factor of 0.957 . 
Table S2. IRMPD absorptions of $\left[\mathrm{PtCl}\left(\mathrm{NH}_{3}\right)_{2}\left(\mathrm{H}_{2} \mathrm{O}\right)(\mathrm{Met})\right]^{+}$ions and calculated vibrational frequencies $\left(\mathrm{cm}^{-1}\right)$ for ec1_1 and ec1_2. Calculated intensities are reported in brackets $\left(\mathrm{km} \mathrm{mol}^{-1}\right)$. Modes with intensity lower than $15 \mathrm{~km} \mathrm{~mol}^{-1}$ are omitted.
Calculated $\#$
Experimental
Vibrational mode

$$
\text { ec1_1 ec1_2 } \quad\left[\mathrm{PtCl}\left(\mathrm{NH}_{3}\right)_{2}\left(\mathrm{H}_{2} \mathrm{O}\right)(\mathrm{Met})\right]^{+}
$$

\begin{tabular}{|c|c|c|c|}
\hline \multirow{2}{*}{$\begin{array}{c}990^{\mathrm{a}}(173) \\
1049^{\mathrm{a}}(268)\end{array}$} & & 1000 & $\mathrm{NH}_{2}$ wagging $+\mathrm{CH}_{2}$ rocking \\
\hline & & 1044 & $\mathrm{CN}$ stretch $+\mathrm{H}_{2} \mathrm{O}$ wagging \\
\hline & $1072^{a}(36)$ & 1086 & $\mathrm{CN}$ stretch $+\mathrm{CH}_{2}$ rocking \\
\hline \multirow[t]{5}{*}{$1146^{\mathrm{a}}(232)$} & & 1166 & $\mathrm{C}(\mathrm{O}) \mathrm{O}-\mathrm{H}$ bending \\
\hline & $1124^{\mathrm{a}}(115)$ & & $\begin{array}{c}\mathrm{C}(\mathrm{O}) \mathrm{O}-\mathrm{H} \text { bending }+\mathrm{CH}_{2} \text { twisting }+ \\
\mathrm{NH}_{3} \text { asymm bending }\end{array}$ \\
\hline & $1146^{\mathrm{a}}(72)$ & & $\begin{array}{c}\mathrm{C}(\mathrm{O}) \mathrm{O}-\mathrm{H} \text { bending }+\mathrm{CH}_{2} \text { wagging }+ \\
\mathrm{NH}_{3} \text { asymm bending }\end{array}$ \\
\hline & $1155^{\mathrm{a}}(34)$ & & $\begin{array}{c}\mathrm{C}(\mathrm{O}) \mathrm{O}-\mathrm{H} \text { bending }+\mathrm{CH}_{2} \text { twisting }+ \\
\mathrm{NH}_{3} \text { asymm bending }\end{array}$ \\
\hline & $1172^{\mathrm{a}}(54)$ & & $\mathrm{C}(\mathrm{O}) \mathrm{O}-\mathrm{H}$ bending $+\mathrm{NH}_{3}$ asymm bending \\
\hline $1185^{\mathrm{a}}(118)$ & & & $\mathrm{NH}_{2}$ twisting $+\mathrm{CH}$ bending \\
\hline $1222^{\mathrm{a}}(1217)$ & & 1273 & $\begin{array}{l}\mathrm{CH} \text { bending }+\mathrm{HO}-\mathrm{H} \text { stretching }+\mathrm{C}(\mathrm{O}) \mathrm{O}-\mathrm{H} \\
\text { bending }+\mathrm{CH}_{2} \text { twisting }\end{array}$ \\
\hline \multirow[t]{2}{*}{$1258^{\mathrm{a}}(783)$} & & & $\mathrm{CH}$ bending $+\mathrm{HO}-\mathrm{H}$ stretching \\
\hline & $1263^{\mathrm{a}}(119)$ & & $\mathrm{NH}_{3}$ (trans $\mathrm{Cl}$ ) umbrella \\
\hline $1271^{\mathrm{a}}(153)$ & & & $\mathrm{CH}$ bending \\
\hline \multirow[t]{2}{*}{$1289^{\mathrm{a}}(380)$} & & & $\mathrm{NH}_{3}$ (trans $\mathrm{Cl}$ ) umbrella \\
\hline & $1296^{a}(122)$ & & $\mathrm{NH}_{3}$ umbrella \\
\hline $1305^{\mathrm{a}}(233)$ & & & $\mathrm{NH}_{3}$ umbrella $+\mathrm{NH}_{2}$ twisting $+\mathrm{CH}_{2}$ twisting \\
\hline $1306^{\mathrm{a}}(230)$ & & & $\mathrm{NH}_{3}$ umbrella \\
\hline $1343^{\mathrm{a}}(629)$ & & 1390 & $\begin{array}{l}\mathrm{C}(\mathrm{O}) \mathrm{O}-\mathrm{H} \text { bending }+\mathrm{CH} \text { bending }+\mathrm{C}=\mathrm{O} \\
\text { stretching }+\mathrm{HO}-\mathrm{H} \text { stretching }\end{array}$ \\
\hline \multirow[t]{2}{*}{$1352^{\mathrm{a}}(92)$} & & & $\mathrm{CH}_{2}$ wagging \\
\hline & $1391^{\mathrm{a}}(21)$ & & $\mathrm{CH}$ bending \\
\hline $1397^{\mathrm{a}}(320)$ & & 1426 & $\mathrm{CH}$ bending $+\mathrm{HO}-\mathrm{H}$ bending \\
\hline $1562^{\mathrm{a}}(69)$ & & 1573 & $\mathrm{NH}_{3}$ (methionine) umbrella \\
\hline $1606^{\mathrm{a}}(41)$ & & & $\mathrm{NH}_{2}$ bending \\
\hline $1619^{a}(44)$ & $1606^{a}(29)$ & 1611 & $\mathrm{NH}_{3}$ bending \\
\hline
\end{tabular}




\begin{tabular}{|c|c|c|c|}
\hline \multirow[t]{3}{*}{$1635^{\mathrm{a}}(52)$} & $1627^{\mathrm{a}}(34)$ & & $\mathrm{NH}_{3}$ bending \\
\hline & $1636^{\mathrm{a}}(41)$ & & $\mathrm{NH}_{3}$ bending \\
\hline & $1641^{\mathrm{a}}(108)$ & & $\mathrm{NH}_{3}$ (methionine) bending \\
\hline $1707^{a}(110)$ & & 1708 & $\mathrm{H}_{2} \mathrm{O}$ scissoring $+\mathrm{C}=\mathrm{O}$ stretching \\
\hline $1764^{\mathrm{a}}(419)$ & $1768^{\mathrm{a}}(238)$ & 1766 & $\mathrm{C}=\mathrm{O}$ stretching $+\mathrm{H}_{2} \mathrm{O}$ scissoring, \\
\hline \multirow[t]{2}{*}{$2906^{\mathrm{b}}(21)$} & $2916^{b}(19)$ & 2943 & $\mathrm{CH}_{2}$ asymm stretching \\
\hline & $3084^{b}(504)$ & 3050 (broad) & $\mathrm{NH}$ of $\mathrm{NH}_{3}$ (methionine) stretching \\
\hline $3255^{b}(144)$ & & 3250 (broad) & $\mathrm{NH}_{2}$ symm stretching \\
\hline \multirow[t]{2}{*}{$3282^{b}(15)$} & & & $\mathrm{NH}_{3}$ symm stretching \\
\hline & $3301^{b}(78)$ & 3300 & $\mathrm{NH}$ of $\mathrm{NH}_{3}$ (methionine) stretching \\
\hline $3346^{b}(54)$ & & 3363 & $\mathrm{NH}_{3}$ asymm stretching \\
\hline $3348^{b}(43)$ & & & $\mathrm{NH}_{2}$ asymm stretching \\
\hline \multirow[t]{2}{*}{$3367^{b}(54)$} & $3353^{b}(45)$ & 3375 & $\mathrm{NH}_{3}$ asymm stretching \\
\hline & $3360^{\mathrm{b}}(58)$ & & $\mathrm{NH}_{3}$ asymm stretching \\
\hline $3383^{b}(31)$ & $3387^{b}(33)$ & 3400 & $\mathrm{NH}_{3}$ asymm stretching \\
\hline $3388^{b}(60)$ & $3391^{b}(51)$ & & $\mathrm{NH}_{3}$ asymm stretching \\
\hline $3552^{b}(201)$ & & 3574 & $\mathrm{HO}-\mathrm{H}$ stretching \\
\hline \multirow[t]{2}{*}{$3575^{b}(115)$} & $3571^{b}(137)$ & & $\mathrm{C}(\mathrm{O}) \mathrm{O}-\mathrm{H}$ stretching \\
\hline & $3636^{\mathrm{b}}(41)$ & 3615 & PtO-H stretching \\
\hline
\end{tabular}

\footnotetext{
"Theoretical IR frequencies were computed at B3LYP/BS1 level of theory.

${ }^{a}$ Frequencies are scaled by a factor of 0.974.

b Frequencies are scaled by a factor of 0.957 .
} 
Table S3: Cartesian coordinates of transition state computed for the aqua ligand substitution reaction of cis- $\left[\mathrm{PtCl}\left(\mathrm{NH}_{3}\right)_{2}\left(\mathrm{H}_{2} \mathrm{O}\right)\right]^{+}$with Met

$\begin{array}{llll}\mathrm{H} & 2.994278 & -0.342018 & -1.015799 \\ \mathrm{C} & 3.387284 & -0.247360 & 0.002416 \\ \mathrm{C} & 4.895141 & -0.476204 & -0.108112 \\ \mathrm{O} & 5.475580 & -1.390714 & 0.412460 \\ \mathrm{C} & 3.066246 & 1.164105 & 0.512222 \\ \mathrm{~N} & 2.755195 & -1.284033 & 0.831008 \\ \mathrm{H} & 3.493160 & 1.884168 & -0.185441 \\ \mathrm{H} & 3.567552 & 1.321181 & 1.474656 \\ \mathrm{O} & 5.485780 & 0.447526 & -0.882250 \\ \mathrm{H} & 6.433659 & 0.242693 & -0.935604 \\ \mathrm{Pt} & -1.722375 & -0.313712 & -0.100216 \\ \mathrm{O} & 0.124782 & -1.790971 & 0.338524 \\ \mathrm{~N} & -3.755949 & 0.027694 & -0.128590 \\ \mathrm{H} & -4.057994 & 0.644132 & -0.879567 \\ \mathrm{H} & -4.316884 & -0.820721 & -0.163959 \\ \mathrm{H} & -3.954841 & 0.493936 & 0.760631 \\ \mathrm{~N} & -1.576121 & -1.337932 & -1.925618 \\ \mathrm{H} & -1.258090 & -0.747589 & -2.691496 \\ \mathrm{H} & -0.851900 & -2.037951 & -1.755668 \\ \mathrm{H} & -2.406807 & -1.828895 & -2.246559 \\ \mathrm{Cl} & -1.781714 & 0.691345 & 1.966179 \\ \mathrm{C} & 1.578960 & 1.443944 & 0.717869 \\ \mathrm{H} & 1.441224 & 2.475794 & 1.037298 \\ \mathrm{H} & 1.143790 & 0.811661 & 1.489124 \\ \mathrm{~S} & 0.573624 & 1.228254 & -0.806939 \\ \mathrm{C} & -0.178523 & 2.874556 & -0.962496 \\ \mathrm{H} & -0.785396 & 3.097460 & -0.087145 \\ \mathrm{H} & -0.806675 & 2.857367 & -1.851850 \\ \mathrm{H} & 0.600180 & 3.624001 & -1.095011 \\ \mathrm{H} & 1.086917 & -1.543988 & 0.543978 \\ \mathrm{H} & -0.178357 & -2.312907 & 1.091219 \\ \mathrm{H} & 2.952699 & -1.101108 & 1.813335 \\ \mathrm{H} & 3.214221 & -2.173660 & 0.641856\end{array}$

